\title{
digitalcommons.nyls.edu
}

2011

Exposing the Underground Establishment Clause in the Supreme Court's Abortion Cases

Justin Murray 


\title{
REGENT UNIVERSITY \\ LAW REVIEW
}

\begin{tabular}{lll}
\hline Volume 23 & 2010-2011 & Number 1 \\
\hline
\end{tabular}

\section{EXPOSING THE UNDERGROUND ESTABLISHMENT CLAUSE IN THE SUPREME COURT'S ABORTION CASES}

\author{
Justin Murray*
}

\begin{abstract}
In Roe v. Wade, the Supreme Court held that women have a right to abortion under the Due Process Clause of the Fourteenth Amendment. The Court reasoned toward this conclusion by importing concepts and concerns that are ordinarily associated with the Establishment Clause. This Article is the first attempt to systematically describe, and critically evaluate, the Court's use of Establishment Clause ideas in Roe and later abortion cases.

Some brief background is essential in order to see how the Court wove Establishment Clause themes into the structure of its Due Process analysis. The Due Process Clause prohibits the government from restricting fundamental constitutional liberties (such as abortion) unless it has a compelling reason for doing so. States have defended their abortion laws by arguing that protecting unborn human life against homicide is a compelling reason to restrict abortion. This argument, advanced in Roe, directly presented the Supreme Court with the question of whether fetuses are human beings entitled to protection against homicide.

The Court, however, refused to answer the question and provided an ambiguous explanation for its refusal. Careful interpretation of these hazy passages reveals the Court's underlying concern that neither the judiciary nor the legislature may decide the question of fetal humanity because the question is religious in nature and divides people along religious lines. When the ambiguities are unraveled and the Court's

- J.D. 2010, Georgetown University Law Center; B.A. 2007, Harvard University; Law Clerk to The Honorable Alexander Williams, Jr., United States District Court Judge, District of Maryland. I would like to thank Laurence Tribe, Rick Garnett, Robin West, Mark Chopko, Brad Klingele, Michael Perry, and above all my wife, Sarah Murray, for their insightful feedback and encouragement.
\end{abstract}


rationale is plainly stated in this way, it becomes clear that Roe's method of analysis incorporates the Establishment Clause requirement that legislation must be based on a secular purpose and the (now-outdated) Establishment Clause goal of alleviating political divisiveness along religious lines.

The Court's analysis is misguided, however, because Establishment Clause principles permit governmental protection of fetal life. The humanity of the fetus can be plausibly based, not only on religious grounds, but also on the secular grounds of philosophical, historical, and experiential reasoning. To be clear, I do not argue that these secular grounds prove beyond dispute that fetuses are human beings. Instead, I defend the more modest proposition that a debatable secular case can be made for viewing fetuses as human beings. This conclusion is not sufficient to justify legal restrictions on abortion (which is not the point of this Article), but it does show that such restrictions do not violate the Establishment Clause, that the Court's implicit reliance on Establishment Clause themes is misplaced, and that we should reopen social and judicial dialogue about the ethical status of fetal life and the constitutional status of abortion.

\section{INTRODUCTION}

In America's fierce debate about the morality and legality of abortion, abortion-rights opponents are frequently criticized for seeking to impose their religious views on others and for breaching the separation between church and state. During the 2008 election campaign, then-Senator Joe Biden indicated that although he considers abortion morally wrong as a "matter of faith," he also finds it inappropriate to "impose that judgment on everyone else" through legal restrictions. ${ }^{1}$ More recently, the efforts of Bart Stupak, Ben Nelson, and other pro-life democrats to exclude abortion from health-care-reform legislation have been widely characterized as "a brazen and frank attempt to impose a minority's religious worldview on the entirety of American healthcare." ${ }^{2}$ Nor has the Supreme Court been left unscathed: some critics attributed its 2007 decision upholding Congress's ban on

1 Meet the Press (NBC television broadcast Sept. 7, 2008), available at http://www. msnbc.msn.com/id/26590488/page/4/.

2 Marci A. Hamilton, Why the Stupak Amendment to the Healthcare Reform Bill Is Unconstitutional, FINDLAW'S WRIT (Nov. 12, 2009), http://writ.news.findlaw.com/hamilton/ 20091112.html. 
partial-birth abortion ${ }^{3}$ to the "telling" fact that five out of the nine justices were Catholic. ${ }^{4}$

Concerns such as these have shaped not only popular discourse about abortion, but constitutional discourse as well. Many critics of antiabortion laws have grounded their position in the Establishment Clause of the First Amendment, which states that "Congress shall make no law respecting an establishment of religion." ${ }_{5}$ The late Justice Stevens, ${ }^{6}$ prochoice litigants, ${ }^{7}$ and many scholars argue that abortion restrictions "lack a secular purpose" and "place the state on one side of a political issue which is divided along religious lines, thus violating the [E]stablishment [C]lause."8

3 Gonzales v. Carhart, 550 U.S. 124, 168 (2007).

4 Geoffrey R. Stone, Our Faith-Based Justices, HufFington PosT (Apr. 20, 2007, 2:45 PM), http://www.huffingtonpost.com/geoffrey-r-stone/our-faithbased-justices_b_46398. html.

5 U.S. CONST. amend. I.

6 Justice Stevens's Establishment Clause argument against abortion laws, as he has articulated it in his judicial opinions, is discussed at greater length below. See infra Parts I.B.3, II.C.3, and III.C. On at least one occasion, Justice Stevens advanced this sort of argument outside of the context of a judicial opinion. See John Paul Stevens, The Bill of Rights: A Century of Progress, 59 U. CHI. L. REV. 13, 30-33 (1992).

7 In many of the Supreme Court's leading abortion cases, one or more pro-choice amici (and occasionally the pro-choice party) advanced an Establishment Clause challenge. See, e.g., Brief Amicus Curiae on Behalf of New Women Lawyers et al. at 47-55, Roe v. Wade, 410 U.S. 113 (1973) (Nos. 70-18 \& 70-40); Brief of Appellees at 92, Harris v. McCrae, 448 U.S. 297 (1980) (No. 79-1268); Brief of Ams. United for Separation of Church and State as Amicus Curiae in Support of Appellees, Webster v. Reprod. Health Servs., 492 U.S. 490 (1989) (No. 88-605) (focusing entirely on the Establishment Clause); Brief of Amici Curiae Religious Coal. for Reprod. Choice et al. at 6, Stenberg v. Carhart, 530 U.S. 914 (2000) (No. 99-830).

8 John Morton Cummings, Jr., Comment, The State, the Stork, and the Wall: The Establishment Clause and Statutory Abortion Regulation, 39 CATH. U. L. REV. 1191, 1193 (1990); see also RONALD DWORKIN, LIFE's DOMINION 24-28 (1993); JOEL FEINBERG, Abortion, in FreEdom AND FUlfillment: PhILOSOPHICAL ESSAYS 37, 75 (1992); U.S. COMM'N ON CIVIL RIGHTS, CONSTITUTIONAL ASPECTS OF THE RIGH'T TO LIMIT CHILDBEARING 35-36 (1975); Peter S. Wenz, Abortion Rights as Religious Freedom 170-81 (1992); Joel R. Cornwell, The Concept of Brain Life: Shifting the Abortion Standard Without Imposing Religious Values, 25 DUQ. L. REV. 471, 473 (1987); David R. Dow, The Establishment Clause Argument for Choice, 20 Golden GATE U. L. REV. 479, 479-80 (1990); Robert L. Maddox \& Blaine Bortnick, Webster v. Reproductive Health Services: Do Legislative Declarations that Life Begins at Conception Violate the Establishment Clause?, 12 CAmpBell L. REv. 1, 2-3 (1989); Joseph S. Oteri et al., Abortion and the Religious Liberty Clauses, 7 HARV. C.R.-C.L. L. REV. 559, 588-91 (1972); Larry J. Pittman, Embryonic Stem Cell Research and Religion: The Ban on Federal Funding as a Violation of the Establishment Clause, 68 U. PITT. L. REv. 131, 135 (2006); Stuart Rosenbaum, Abortion, the Constitution, and Metaphysics, 43 J. CHURCH \& STATE 707, 713-14 (2001); Edward L. Rubin, Sex, Politics, and Morality, 47 WM. \& MARY L. REv. 1, 40-46 (2005); Paul D. Simmons, Religious Liberty and Abortion Policy: Casey as "Catch-22", 42 J. CHURCH \& STATE 69, 69 (2000); Paul D. Simmons, Religious Liberty and the Abortion Debate, $32 \mathrm{~J}$. CHURCH \& STATE 567, 568 (1990); Gila Stopler, "A Rank Usurpation of Power"-The Role of 
The Supreme Court has never openly endorsed these efforts to base abortion rights on the First Amendment. 9 Nonetheless, I show that Establishment Clause concepts play a central, albeit veiled (and therefore largely unnoticed), role in the Court's understanding of the constitutional right to abortion. ${ }^{10}$ This Article provides a new way of interpreting Roe $v$. Wade and subsequent abortion cases: the Court implicitly relies upon First Amendment-type arguments to justify abortion rights, but without ever explicitly referring to the First Amendment. Because the Court's reliance on the Establishment Clause is never directly acknowledged in the text of its abortion-rights opinions, I call this dynamic the "underground Establishment Clause," or, for convenience, the "UEC."

This reinterpretation of abortion-rights jurisprudence is particularly timely in light of the new membership on the Court and Justice Kennedy's uncertain and evolving views about abortion rights. In 1992, Kennedy surprised many observers by authoring part of the plurality opinion that reaffirmed Roe by a narrow margin." His portion of the opinion heavily emphasized (what I will show to be) UEC themes: that

Patriarchal Religion and Culture in the Subordination of Women, 15 DUKE J. GENDER L. \& POL'Y 365, 391-93 (2008); Elizabeth Symonds, The Denial of Medi-Cal Funds for Abortion: An Establishment of Religion, 9 GoLdEN GaTE U. L. REV. 421, 430-33 (1979); Karen F.B. Gray, Comment, An Establishment Clause Analysis of Webster v. Reproductive Health Services, 24 GA. L. REV. 399, 402 (1990); Sherryl E. Michaelson, Note, Religion and Morality Legislation: A Reexamination of Establishment Clause Analysis, 59 N.Y.U. L. REV. 301, 401-07 (1984); Note, New Jersey's Abortion Law: An Establishment of Religion?, 25 Rutgers L. REV. 452, 453 (1971). Professor Laurence Tribe used to take this position, see Laurence H. Tribe, The Supreme Court, 1972 Term-Foreword: Toward a Model of Roles in the Due Process of Life and Law, 87 HARV. L. REV. 1, 19-24 (1973), but he has since abandoned it, see LAURENCE H. TRIBE, ABORTION: The Clash OF ABSOLUTES 116 (1990).

9 The Court has only addressed an Establishment Clause objection in the abortion context on one occasion. There, it held that the Hyde Amendment does not violate the Establishment Clause. Harris v. McRae, 448 U.S. 297, 319-20 (1980). In Part II.B below, I explain why this holding clarifies, rather than contradicts, my thesis about the underground Establishment Clause.

10 Some aspects of the connection between abortion-rights jurisprudence and the Establishment Clause have been identified, and other aspects misidentified, in previous scholarship. See Michael W. McConnell, The Selective Funding Problem: Abortions and Religious Schools, 104 HARV. L. REV. 989, 994-96 (1991). Professor McConnell argued that Roe is to abortion what the Establishment Clause is to religion, because Roe demands that the government remain neutral about abortion. Id. at 996 . His analysis is on the right track, but it is incomplete and, at points, inaccurate. As I will show, the Court does not require complete governmental neutrality about abortion. It requires neutrality about one important aspect of abortion: whether a pre-viable fetus is a human being. Nonetheless, the Court permits most governmental restrictions on abortion short of those that treat previable fetuses like full-fledged human beings. This Article is an effort to explain that discrepancy. See discussion infra Part II.

11 Planned Parenthood of Southeastern Pennsylvania v. Casey, 505 U.S. 833, 84546 (1992) (plurality opinion). 
pregnancy and abortion deeply implicate our most basic ethical and religious ideas about "existence, of meaning, of the universe, and of the mystery of human life," and therefore that the government must not "mandate" its own moral view on the subject. ${ }^{12}$ More recently, however, his opinions in Stenberg v. Carhart and Gonzales v. Carhart, the partialbirth-abortion cases, sharply turned against the UEC by emphasizing the humanity of fetal life and by permitting the government to "take sides in the abortion debate and come down on the side of life, even life in the unborn." 13 This Article will show how Kennedy's shifting views about abortion rights relate to the UEC, and why his Carhart opinions threaten the inner logic and future of Roe and the Court's other abortionrights decisions. ${ }^{14}$

The following provides a brief description of what the UEC is and why it is problematic. The Court has located the constitutional right to abortion in the Due Process Clause of the Fourteenth Amendment. ${ }^{15} \mathrm{My}$ task, therefore, is to identify where Establishment Clause themes enter into and influence the Court's Due Process reasoning.

One of the general principles of Due Process is that the government may not infringe upon fundamental rights unless it can provide a compelling reason for doing so. ${ }^{16}$ Once the Roe Court held that abortion is a fundamental right, ${ }^{17}$ the only remaining option for Texas (the respondent in $R o e$ ) to vindicate its abortion statute was to provide a compelling justification for restricting abortion. To that end, Texas offered the following rationale for its law: "the fetus is a human being and the state has an interest in the arbitrary and unjustified destruction of this being." 18

The Court rebuffed Texas's asserted justification, but, interestingly, it did not say that Texas erred in viewing fetuses as human beings deserving of protection. The Court simply refused to answer the question

12 Id. at 850-51; see also discussion infra Part II.D.2.

13 Stenberg v. Carhart, 530 U.S. 914, 961 (2000) (Kennedy, J., dissenting); see Gonzales v. Carhart, 550 U.S. 124, 144-45 (2007) ("[T]he government has a legitimate and substantial interest in preserving and promoting fetal life . . .."); see also discussion infra Part II.E.

14 See infra Part II.E. I also argue that Kennedy's usual method of Establishment Clause interpretation-the coercion test-would readily find anti-abortion laws permissible under the First Amendment, which suggests that he would probably abandon the UEC if litigants and scholars manage to convince him of the underlying links between Establishment Clause case law and abortion-rights jurisprudence. See infra Part I.A.3.

15 Roe v. Wade, 410 U.S. 113, 153 (1973); see U.S. ConST. amend. XIV ("No State shall . . . deprive any person of life, liberty, or property, without due process of law ....").

16 ERWIN CHEMERINSKY, CONSTITUTIONAL LAW: PRINCIPLES AND POLICIES 767 (2d ed. 2002).

17 Roe, 410 U.S. at 152-53.

18 Brief for Appellee at 9, Roe, 410 U.S. 113 (No. 70-18). 
of "when [human] life begins," explaining, in part, that the question is morally and religiously divisive and therefore cannot be appropriately resolved by the judiciary. ${ }^{19}$ The Court concluded that the legislature, too, must not seek to answer the question in a way that precludes women from answering it for themselves. ${ }^{20}$

This line of reasoning closely parallels two of the central themes in Establishment Clause case law: the requirement that all government action must have a "secular legislative purpose," 21 and the idea (in vogue at the time of Roe, but no longer) that "political division along religious lines was one of the principal evils against which the First Amendment was intended to protect." 22 Roe did not condemn the government's purpose of protecting the lives of unborn children for being false, but for being quasi-religious and for dividing society along religious and ethical fault lines. Although these Establishment Clause considerations were decisive for the outcome in Roe, the Court kept the analysis underground by omitting direct citation to or engagement with precedents and limiting principles that might have led to a different outcome.

Justice Stevens and several commentators, by lifting the Establishment Clause issue above ground, have provided a more responsible and elaborate First Amendment objection to abortion restrictions than the one suggested by the UEC. Many of these analyses deliberately distinguish secular purposes from religious ones and explain why the governmental interest in protecting pre-viable fetuses as human persons falls in the latter category. They generally contend (controversially) that religion is based on faith and authority, whereas secular reasoning primarily employs three criteria: "logic," "history," and "shared experiences."23

I argue, however, that protecting fetuses as human persons can be plausibly supported by all three of these criteria, and that a sufficiently strong secular case can be made for restricting abortion to satisfy the Establishment Clause. This does not necessarily mean that legislatures should restrict abortion, or even that abortion rights should not receive constitutional protection in some other form-both of these propositions lie beyond the scope of this Article. Yet my conclusion does indicate that the Supreme Court should revisit the foundations of abortion-rights jurisprudence and provide a more thoughtful analysis of the ethical status of fetal life.

19 Roe, 410 U.S. at 159-60.

20 See discussion infra Part II.A.4-5.

21 Lemon v. Kurtzman, 403 U.S. 602, 612 (1971).

22 Id. at 622 (citing Paul A. Freund, Comment, Public Aid to Parochial Schools, 82 HARV. L. REV. 1680, 1692 (1969)).

23 E.g., Thornburgh v. Am. Coll. of Obstetricians \& Gynecologists, 476 U.S. 747, 779 (1986) (Stevens, J., concurring); see also discussion infra Parts I.B.3, II.C.3, and III.C. 
Part I provides necessary background on current Establishment Clause doctrine and discusses various ways that this doctrine has been applied to challenge abortion restrictions. Part II shows that the arguments introduced in Part I also feature prominently in the Supreme Court's abortion cases. Part III contends that protecting fetal personhood does not violate the Establishment Clause, and that the Court should put an end to the UEC. Part IV concludes.

\section{EstaBlishment Clause OBJECTIONS TO ABORTION RESTRICTIONS}

The Establishment Clause says that "Congress shall make no law respecting an establishment of religion." ${ }_{44}$ This concise text is profoundly difficult to interpret, due to the ambiguity of the words "establishment" and "religion." In this Part, I briefly describe the three primary methods that various Supreme Court justices use to interpret the Establishment Clause. I then introduce three ways that pro-choice commentators have applied these interpretive methods to argue that abortion restrictions violate the First Amendment. ${ }^{25}$

\section{A. Three Tests for Detecting Establishments of Religion}

The three primary legal tests that courts and scholars use to figure out whether governmental actions establish religion are commonly known as the Lemon test, the symbolic-endorsement test, and the coercion test. This Section briefly describes how each test works. One of the three tests (coercion) does not supply any plausible objection to abortion restrictions, so I will examine it in this Section and lay it aside for the remainder of the Article. However, the other two tests (Lemon and symbolic endorsement) provide initially-plausible pro-choice arguments, so I will leave it to the next Section to spell out those objections in detail.

\section{The Lemon Test}

The Lemon test has been the Supreme Court's leading approach to the Establishment Clause for nearly four decades. In Lemon $v$. Kurtzman, the Court held that a law is unconstitutional if any one of

24 U.S. CONST. amend. I.

25 In other words, this Article focuses on Establishment Clause arguments about abortion that are based on currently-existing First Amendment doctrine, as well as the leading minority views proposed by Supreme Court justices. In doing so, I do not mean to imply that these are the only possible interpretations of the First Amendment, or even the best interpretations. It is possible that future commentators will come up with a new method of interpreting the Establishment Clause that differs from the approaches addressed in this Article. If such an attempt is made, it may well require a different kind of rebuttal than the ones that I provide to existing pro-choice Establishment Clause analyses in Part III, infra. 
three circumstances is met: (1) if the law lacks a "secular legislative purpose," (2) if its "primary effect" is to advance or inhibit religion, or (3) if it creates an "excessive government entanglement with religion." 26 Lemon has been the subject of fierce debate and criticism, even among Supreme Court justices, ${ }^{27}$ and the Court has resolved many cases without applying Lemon. ${ }^{28}$ Yet despite these controversies, Lemon has not been overruled and it remains the leading judicial test for determining whether governmental actions violate the Establishment Clause. ${ }^{29}$

The first part of the Lemon analysis condemns laws that are motivated exclusively by religious purposes instead of secular ones. ${ }^{30}$ The Court has only declared laws unconstitutional under the secular-purpose standard in three contexts: governmental promotion of Creation Science over evolution in public schools, ${ }^{31}$ placing the Ten Commandments on public property ${ }^{32}$ and providing a moment of silence for prayer in public schools. $^{33}$ In the vast majority of cases, the Court has classified the government's purpose as secular, including arguably borderline purposes such as religious accommodation, ${ }^{34}$ solemnizing public events, ${ }^{35}$

26403 U.S. at 612-13 (citing Bd. of Educ. v. Allen, 392 U.S. 236, 243 (1968), and quoting Walz v. Tax Comm'n of New York, 397 U.S. 664, 674 (1970)).

27 See, e.g., McCreary County v. ACLU, 545 U.S. 844, 890 (2005) (Scalia, J., dissenting) (collecting criticisms of Lemon by himself and other justices).

28 See, e.g., Marsh v. Chambers, 463 U.S. 783, 795 (1983) (upholding legislative prayer due to its historical longevity, without applying Lemon). Just two years after Lemon, the Court suggested that the Lemon "tests" are "no more than helpful signposts." Hunt v. McNair, 413 U.S. 734, 741 (1973).

29 The Court recently reaffirmed the Lemon test, as interpreted by the symbolicendorsement test, and applied it to strike down a courthouse display of the Ten Commandments. See McCreary County, 545 U.S. at 858, 861-63.

30 See Lynch v. Donnelly, 465 U.S. 668, 681 n.6 (1984) (clarifying that Lemon only requires that laws be partially motivated by a "secular purpose," not that the government must have "exclusively secular" objectives").

31 See Edwards v. Aguillard, 482 U.S. 578, 596-97 (1987); Epperson v. Arkansas, 393 U.S. 97, 107-09 (1968).

32 See McCreary County, 545 U.S. at 881; Stone v. Graham, 449 U.S. 39, $42-43$ (1980) (per curiam). But cf. Van Orden v. Perry, 545 U.S. 677, 681 (2005) (upholding government-sponsored Ten Commandments display).

33 See Wallace v. Jaffree, 472 U.S. 38, 59-61 (1985).

34 See, e.g., Corp. of the Presiding Bishop of the Church of Jesus Christ of LatterDay Saints v. Amos, 483 U.S. 327, 334 (1987) (recognizing legitimate state interest in religious accommodation).

35 See, e.g., Lynch, 465 U.S. at 693 (O'Connor, J., concurring) ("[G]overnment acknowledgments of religion serve, in the only ways reasonably possible in our culture, the legitimate secular purposes of solemnizing public occasions, expressing confidence in the future, and encouraging the recognition of what is worthy of appreciation in society."). 
promoting sexual abstinence for teenagers, ${ }^{36}$ and providing a "uniform day of rest" through mandatory Sunday closing laws. ${ }^{37}$

Most Establishment Clause cases arise under the other two parts of the Lemon test: the "primary effect" and "entanglement requirements." Primary effect and entanglement cases generally deal with governmental aid to religious institutions: parochial schools, ${ }^{38}$ religiously-affiliated service organizations, ${ }^{39}$ employers, ${ }^{40}$ and similar entities. Even if such aid is provided for an indisputably secular purpose, ${ }^{41}$ it is often constitutionally suspect for two reasons. First, when aid is offered to a religious organization to further a secular goal, the organization might divert the aid toward religious activities, so that the ultimate effect of the law is to advance religion. This is the primary effect problem. ${ }^{42}$ Second, in order to avoid the primary effect problem, the government might attach conditions and monitoring to ensure the proper use of aid, giving rise to collaborative and supervisory relationships that blur church-state boundaries and lead to inappropriate mutual influence. This is the entanglement problem. ${ }^{43}$

\section{The Symbolic-Endorsement Test}

This sub-section introduces a close relative of Lemon called the "symbolic endorsement" test. ${ }^{44}$ Symbolic endorsement does not abandon the Lemon framework, but instead reinterprets its secular-purpose and

36 See Bowen v. Kendrick, 487 U.S. 589, 602 (1988) ("AFLA was motivated primarily, if not entirely, by a legitimate secular purpose-the elimination or reduction of social and economic problems caused by teenage sexuality, pregnancy, and parenthood." (citations omitted)); id. at 634 (Blackmun, J., dissenting) ("I have no meaningful disagreement with the majority's discussion of the AFLA's essentially secular purpose....").

37 MeGowan v. Maryland, 366 U.S. 420, 445 (1961).

38 See, e.g., Zelman v. Simmons-Harris, 536 U.S. 639, 643-45 (2002) (addressing a voucher program that includes religious schools).

39 See, e.g., Kendrick, 487 U.S. at 593 (addressing an abstinence-education grant program that includes religious organizations).

40 See, e.g., Corp. of the Presiding Bishop of the Church of Jesus Christ of LatterDay Saints v. Amos, 483 U.S. 327, 329-30 (1987) (addressing the applicability of Title VII religion exemptions to the secular, nonprofit activities of a Mormon employer).

41 In most of these cases, the secular purpose of the law is not in doubt. See, e.g., Lemon v. Kurtzman, 403 U.S. 602, 613 (1971) (recognizing legitimate state interest in educational quality, including religious schools); Corp. of the Presiding Bishop, 483 U.S. at 334 (recognizing legitimate interest in accommodating religion).

42 See Lemon, 403 U.S. at 612.

43 See id. at 619 ("A comprehensive, discriminating, and continuing state surveillance will inevitably be required to ensure that [aid conditions] are obeyed and the First Amendment otherwise respected.").

44 ChEMERINSKY, supra note 16, at 1151. The symbolic-endorsement test originated in Lynch v. Donnelly, 465 U.S. 668, 687-94 (1984) (O'Connor, J., concurring), and the Court has used it in numerous majority opinions, most recently in $M c$ Creary County $v$. ACLU, 545 U.S. 844, 860 (2005). 
primary-effect requirements. The secular-purpose requirement remains largely the same as it was under Lemon: it condemns government policies that intentionally favor some religions and disfavor others. The reinterpreted primary-effect requirement is more novel and significant: it condemns government actions if a reasonable person would perceive those actions as favoring religion, even if the actions are not actually motivated by religious favoritism. ${ }^{45}$

Typical examples of symbolic-endorsement problems involve governmental promotion of prayer in public schools, ${ }^{46}$ crosses on government property, ${ }^{47}$ or government-sponsored Christmas displays that celebrate Christ's birth. ${ }^{48}$ In cases like these, the government is arguably motivated solely by the secular purpose of celebrating America's history and heritage. ${ }^{49}$ Yet despite secular intentions, proponents of the endorsement test would deem the government's actions unconstitutional as long as a reasonable person would perceive the government's actions as favoring religion. ${ }^{50}$

\section{The Coercion Test}

Although Lemon and its symbolic-endorsement offshoot have long been the leading methods for Establishment Clause inquiry, they remain highly controversial. ${ }^{51}$ Many critics urge the Court to replace Lemon with

45 E.g., Lynch, 465 U.S. at 690 (O'Connor, J., concurring). Proponents of the endorsement test agree on this much. They disagree, however, about how reasonable the reasonable person must be. Compare Capitol Square Review \& Advisory Bd. v. Pinette, 515 U.S. 753, 780-81 (1995) (O'Connor, J., concurring in the judgment) (arguing that the reasonable observer "must be deemed aware of the history and context of the community and forum in which the religious display appears"), with id. at 799-800 n.5 (Stevens, J., dissenting) (arguing that the reasonable observer is a passerby who notices the government's display, not Justice O'Connor's "well-schooled jurist"). A majority of the Court embraced Justice O'Connor's formulation in McCreary County, 545 U.S. at 866.

46 See, e.g., Santa Fe Indep. Sch. Dist. v. Doe, 530 U.S. 290, 309-10 (2000) (applying endorsement test to hold that public schools allowing student-initiated prayer at school football games violates the First Amendment).

47 See Pinette, 515 U.S. at 798-99 (Stevens, J., dissenting) (applying endorsement test to invalidate governmental permission for the $\mathrm{KKK}$ to place a Latin cross on government property). But cf. id. at 772 (O'Connor, J., concurring in part and concurring in the judgment) (applying endorsement test to reach the opposite result).

48 See, e.g., County of Allegheny v. ACLU, 492 U.S. 573, 598-601 (1989) (applying endorsement test to hold that government-sponsored Christmas crèche violates the First Amendment). But cf. Lynch, 465 U.S. at 687 (upholding a different crèche display).

49 For one of the Court's many recognitions of the legitimacy of this purpose, see Lynch, 465 U.S. at $680-81$.

50 See text accompanying supra note 45.

51 See supra notes 27-28 and accompanying text. 
a coercion-oriented standard. ${ }^{52}$ This sub-section addresses the coercionbased alternative to Lemon.

Unlike the other Establishment Clause frameworks, the coercion test generally allows the government to promote religious ideas and goals, as long as it does not force people to participate in religious exercises. ${ }^{53}$ This view has three known advocates on the current Court: Justices Scalia, Thomas and Kennedy. ${ }^{54}$ Chief Justice Roberts, and Justices Alito, Sotomayor and Kagan, have not yet revealed their views on the subject. When such a case comes before the Court, it is probable that Alito and Roberts will adopt the coercion test, creating a slim majority on the Court to overrule or seriously modify Lemon. ${ }^{55}$ (Very little is known about the views of Justices Sotomayor and Kagan, but there are no indications that they would abandon Lemon in favor of a coercion standard. ${ }^{56}$ ) Thus, although the coercion test represents a

52 See, e.g., Michael W. McConnell, Coercion: The Lost Element of Establishment, 27 WM. \& MARY L. REV. 933, 940 (1986).

53 See County of Allegheny, 492 U.S. at 659 (Kennedy, J., concurring in the judgment in part and dissenting in part) ("Our cases disclose two limiting principles: government may not coerce anyone to support or participate in any religion or its exercise; and it may not, in the guise of avoiding hostility or callous indifference, give direct benefits to religion ...." (citation omitted)); see also Lee v. Weisman, 505 U.S. 577, 586 (1992) ("These dominant facts mark and control the confines of our decision: State officials direct the performance of a formal religious exercise ... for secondary schools." (emphasis added)); Bd. of Educ. v. Mergens, 496 U.S. 226, 261 (1990) (Kennedy, J., concurring in part and concurring in the judgment) ("The inquiry with respect to coercion must be whether the government imposes pressure upon a student to participate in a religious activity."). Justices Scalia, Thomas, and Kennedy agree on this much, but they sometimes disagree about what counts as "coercion." Compare Lee, 505 U.S. at 594 (Kennedy, J., opinion of the Court) ("[G]overnment may no more use social pressure to enforce orthodoxy than it may use more direct means."), with id. at 632 (Scalia, J., dissenting) ("[T] he Court invents a boundless, and boundlessly manipulable, test of psychological coercion . . ..").

54 The Court unanimously agrees that coerced religious exercise is sufficient to prove an Establishment Clause violation, but previous Court majorities have rejected the Scalia-Thomas-Kennedy view that coercion is a necessary element. Compare Lee, 505 U.S. at 587 (Kennedy, J., opinion of the Court) (" $[\mathrm{A}] \mathrm{t}$ a minimum, the Constitution guarantees that government may not coerce anyone to support or participate in religion or its exercise...."), with id. at 604 (Blackmun, J., concurring) ("Although our precedents make clear that proof of government coercion is not necessary to prove an Establishment Clause violation, it is sufficient.").

55 See Julie F. Mead, Preston C. Green \& Joseph O. Oluwole, Re-examining the Constitutionality of Prayer in School in Light of the Resignation of Justice O'Connor, $36 \mathrm{~J}$. L. \& EDUC. 381, 394-98, 406 (2007).

56 See David M. Estes, Justice Sotomayor and Establishment Clause Jurisprudence: Which Antiestablishment Standard Will Justice Sotomayor Endorse?, 11 RuTGERS J.L. \& REL. 525, 539 (2010) ("[T]he depth of analysis and space she has devoted to the Endorsement test suggests that Justice Sotomayor prefers the neutrality theory of the antiestablishment principle."); ALLIANCE FOR JUSTICE, REPORT ON ELENA KAGAN 9-13 (2010) (summarizing the few available clues regarding Justice Kagan's interpretation of the Establishment Clause). 
minority position in the Court's existing jurisprudence, it could soon become the majority position.

For that reason, it is worth examining whether a plausible objection could be made to anti-abortion laws within the parameters of the coercion test. No commentator has yet invoked the coercion test to argue against abortion laws. The closest argument-and a common one-is that abortion restrictions graft religiously-motivated ideas into the law and "coerce] into conformity" people from other religions who disagree. ${ }^{57}$ Some commentators have used a similar coercion based argument to show that abortion restrictions violate the Free Exercise Clause. ${ }^{58}$

This argument does focus on coercion, but not in the way that the Establishment Clause coercion test calls for. The test does not ask whether religiously-motivated laws coerce unwilled conduct (which would effectively smuggle the Lemon secular-purpose inquiry into the coercion test), but whether the act coerced by the government is a "religious exercise." 59 Even if opposition to abortion is based on religious motivations, the act of carrying a pregnancy to term is not plausibly characterized as a religious exercise: pregnancy, wanted or unwanted, is an ordinary human experience that does not uniquely belong to any religion at the exclusion of others. ${ }^{60}$ However coercive anti-abortion laws might be, they do not coerce religious exercise and therefore do not run afoul of the coercion test.

Thus, the remainder of the Article will focus on the more plausible pro-choice arguments that are based on Lemon and the symbolicendorsement test. Nonetheless, the conclusion of this sub-section-that the coercion test leaves no room for a pro-choice Establishment Clause challenge-has independent practical significance. Justice Kennedy, the fence-sitter in abortion cases, is one of the judicial architects and proponents of the coercion test. If my UEC interpretation of the Supreme

57 Cummings, supra note 8 , at 1230 n.73.

58 See, e.g., Oteri et al., supra note 8, at 592-96.

59 See cases cited supra note 53. This feature of the coercion test makes it vulnerable to the criticism that it makes the Establishment Clause redundant with the Free Exercise Clause. See Suzanna Sherry, Lee v. Weisman: Paradox Redux, 1992 SuP. CT. REV. 123, 134. It is not my purpose here to defend (or criticize) the coercion test, but only to clarify how it is applied by those who adhere to it.

60 Cf. Lee v. Weisman, 505 U.S. 577, 586-87 (1992) (holding that prayer at a public school graduation is a "state-directed religious exercise," but that severe facts like these "mark and control the confines of our decision"); id. at 640-41 (Scalia, J., dissenting) (describing coercion understood through historical examples or religious establishment as "coercion of religious orthodoxy and of financial support by force of law and threat of penalty. Typically, attendance at the state church was required; only clergy of the official church could lawfully perform sacraments; and dissenters, if tolerated, faced an array of civil disabilities."). 
Court's abortion precedents is correct, ${ }^{61}$ then pro-life litigants and amici should, in an appropriate case, try to persuade Kennedy to reject Roe's implicit Lemon flavored analysis and apply his usual, coercion-oriented inquiry instead. The predictable outcome of that inquiry, if Kennedy were to undertake it, would be that abortion restrictions are constitutionally permissible for purposes of the Establishment Clause. ${ }^{62}$ This conclusion would provide him with an opening to re-examine the foundations of abortion-rights jurisprudence.

\section{B. Three Establishment Clause Objections to Restrictive Abortion Laws}

Within the general framework of Lemon and the symbolicendorsement test, pro-choice commentators have articulated three objections to restrictive abortion laws. First, abortion sharply divides people of different religious persuasions, and the primary political support for restrictive abortion laws comes from religious believers; therefore, such laws are unconstitutional. ${ }^{63}$ For convenience, I call this the "political divisiveness" argument. ${ }^{64}$

Second, the morality of abortion involves a variety of fundamental questions about human existence and ethics, such as: what is man; why do we value him; and, when does developing human life become morally valuable? Political resolution of ultimate human concerns such as these is inappropriate, because such issues lie within the domain of religion, not government. ${ }^{65}$ This is the "ultimate concerns" argument. ${ }^{66}$

Third, opposition to abortion is based on faith and obedience to religious precepts, not secular forms of reasoning and justification. The Constitution requires laws to be based on secular ways of thinking about

61 See infra Part II.

62 I will later argue, in Part III, infra, that abortion restrictions are constitutionally permissible even under a Lemon or symbolic-endorsement approach to the Establishment Clause. My only point for the time being is that the constitutional validity of anti-abortion laws is more obvious under the coercion test than it is under Lemon, and therefore that proponents of the coercion test-such as Kennedy-may be quicker than other justices to reject the UEC.

63 See infra Part I.B.1.

64 The phrase is not my own. It has been used extensively in Supreme Court decisions and scholarly commentary. For an elaborate discussion of the politicaldivisiveness concept in the Establishment Clause context, see Richard W. Garnett, Religion, Division, and the First Amendment, 94 GEO. L.J. 1667 (2006).

65 See infra Part I.B.2.

66 Like political divisiveness, "ultimate concerns" is a well-established judicial and scholarly position on the definition of religion, based on the Supreme Court's conscientiousobjector cases. See Stanley Ingber, Religion or Ideology: A Needed Clarification of the Religion Clauses, 41 STAN. L. REV. 233, 267-72 (1989). 
the world, not religious ones. ${ }^{67}$ This is the "faith-versus-reason" argument.

These three arguments require careful exposition in this Section, because the central theses of this Article-that the Supreme Court's abortion-rights opinions use much the same arguments, and that these arguments are misguided-revolve around them.

\section{Political Divisiveness}

The first and most common argument for why restrictive abortion laws violate the Establishment Clause is the political-divisiveness argument. The doctrinal foundation for the divisiveness argument lies in Supreme Court decisions from the 1970s, most notably Lemon. In Lemon, Chief Justice Burger argued that "political division along religious lines was one of the principal evils against which the First Amendment was intended to protect."68 Although ordinary political debate is "normal and healthy" in a democracy, he argued that political issues where people's "votes aligned with their faith" are "a threat to the normal political process." 69 Consequently, he argued that the "divisive political potential" of a law is evidence that it unconstitutionally entangles church and state. ${ }^{70}$

More recently, a bare majority of the Supreme Court has completely rejected these earlier concerns about the political divisiveness of religion. ${ }^{71}$ Furthermore, the Court has unanimously agreed that divisiveness alone is not sufficient to prove an Establishment Clause violation: something more must be shown. ${ }^{72}$ Nonetheless, a minority of

67 See infra Part I.B.3.

68 Lemon v. Kurtzman, 403 U.S. 602, 622 (1971) (citing Freund, supra note 22, at 1692). But see Garnett, supra note 64, at 1670 ("It is both misguided and quixotic, then, to employ the First Amendment to smooth out the bumps and divisions that are an unavoidable part of the political life of a diverse and free people and, perhaps, best regarded as an indication that society is functioning well.").

69 Lemon, 403 U.S. at 622. For Burger, religion-related political division threatens to replicate the troubled "history" of persecution that results when religion and government converge, and it also "divert[s] attention from the myriad issues and problems" that Americans of all religions can rationally debate and potentially agree upon. Id. at 623 .

$70 I d$, at 622.

71 See, e.g., Zelman v. Simmons-Harris, 536 U.S. 639, 662 n.7 (2002) (Rehnquist, C.J., delivering the opinion of the Court, joined by O'Connor, Scalia, Kennedy, and Thomas, JJ.) ("The dissent resurrects the concern for political divisiveness that once occupied the Court but that post-Aguilar cases have rightly disregarded." (quoting Mitchell v. Helms, 530 U.S. 793, 825 (2000) (plurality opinion))).

72 See, e.g., Lynch v. Donnelly, 465 U.S. 668, 684 (1984) ("[T]his Court has not held that political divisiveness alone can serve to invalidate otherwise permissible conduct."); id. at 689 (O'Connor, J., concurring) ("[P]olitical divisiveness along religious lines should not be an independent test of constitutionality."); id. at 703 (Brennan, J., dissenting) ("Of 
the justices continues to view divisiveness as a significant factor in Establishment Clause analysis, ${ }^{73}$ and unease about religion-related conflict is widespread in contemporary American political discourse generally, ${ }^{74}$ and in the abortion debate specifically.

When applied to abortion, the basic form of the political-divisiveness argument is that the "major force behind the antiabortion movement is a large and well organized group of religious organizations"; therefore, anti-abortion laws violate the Establishment Clause. ${ }^{75}$ Three variations of the argument all fit within this core template. The first variation grounds political-divisiveness concerns in the entanglement part of the Lemon test, as Chief Justice Burger had done in his Lemon opinion. ${ }^{76}$ The entanglement variation argues that due to the "pervasive" involvement of "organized religious groups" in the abortion controversy, governmental anti-abortion efforts result in "a union of government and religion [that] tends to destroy government and to degrade religion." 77

The second variation relies on the symbolic-endorsement framework instead. ${ }^{78}$ This argument states that, in light of the religious divisions surrounding the abortion issue, a reasonable observer would "perceive" anti-abortion laws as reflecting governmental favoritism toward "theologically conservative view[s] on abortion."79 As a result, such laws enable "Roman Catholics and fundamentalist Christians" to view themselves as "political "insiders," whereas they make other religious and nonreligious groups feel "alienated" and "condemned" as "political "outsiders."'80

course, the Court is correct to note that we have never held that the potential for divisiveness alone is sufficient to invalidate a challenged governmental practice ....").

73 See, e.g., Van Orden v. Perry, 545 U.S. 677, 709 (2005) (Stevens, J., dissenting, joined by Ginsburg, J.) ("Government's obligation to avoid divisiveness and exclusion in the religious sphere is compelled by the Establishment and Free Exercise Clauses . . .."); Zelman, 536 U.S. at 717-18 (Breyer, J., dissenting) (writing separately to emphasize that "protecting the Nation's social fabric from religious conflict" is a fundamental purpose of the First Amendment).

74 See Garnett, supra note 64, at 1675-76.

75 See, e.g., Cummings, supra note 8 , at 1231-32.

76 See supra notes 69-70 and accompanying text.

77 Tribe, The Supreme Court, 1972 Term, supra note 8, at 22, 23 (quoting Engel v. Vitale, 370 U.S. 421,431 (1962)).

78 This should be no surprise, because the endorsement test relies on many of the "same premises and concerns" as Lemon's political-divisiveness analysis: "asking whether a reasonable observer would regard herself as having been cast by state action as an outsider in the political community seems consonant with, if not equivalent to, asking whether that same state action does or could cause political divisiveness." Garnett, supra note 64, at 1699-1700.

79 Gray, supra note 8, at 415-16.

80 Id. at 416 (quoting Lynch v. Donnelly, 465 U.S. 668, 688 (1984) (O’Connor, J., concurring)) 
A third variation sees the intense religious divisions regarding abortion as circumstantial evidence that anti-abortion laws are motivated by religion, in violation of the Lemon secular-purpose requirement. This inference appears to lurk as an inchoate suspicion in the background of many, perhaps even most, Establishment Clause objections to abortion laws. ${ }^{81}$ Several pro-choice commentators have made the point more directly by arguing, for instance, that "religious values [such as anti-abortion sentiment] can be recognized," and distinguished from secular "cultural values," by "the presence of truly radical divisiveness surrounding them." 82

\section{Ultimate Concerns}

The ultimate-concerns argument is based on the secular-purpose requirement of the Lemon test. Secular-purpose arguments about abortion are complicated by a crucial gap in existing case law: the Supreme Court's Establishment Clause decisions, including those involving the secular-purpose requirement, have never explained how to distinguish a religious purpose from a secular one. In the few situations where the Court has struck down a law for lack of a secular purpose, 83 the Court never had to confront the thorny question of how to define and differentiate secular and religious purposes.

In each of those cases, one party accused the government of having a clearly religious purpose (for example, teaching Creationism in order to advance the Bible's creation story), and the government defended by claiming that its real purpose is a different, clearly secular one (for example, teaching Creationism to promote the findings of objective biological science, or to promote diversity of ideas). ${ }^{84}$ The Court's only task was to figure out, largely by looking to legislative history, whether the government's stated (secular) purpose was its actual purpose, or whether the stated purpose was a "sham" to disguise its true, religious purpose. ${ }^{85}$

81 A shocking number of pro-choice commentators emphasize, as their primary or exclusive evidence that abortion restrictions are based on religious purposes rather than secular ones, the fact that most people who strongly oppose abortion are Christian. See, e.g., Gray, supra note 8, at 417-18.

82 Dow, supra note 8 , at 497.

83 As I discussed previously, the only programs that the Supreme Court has struck down on secular-purpose grounds are: governmental support for Creationism in public schools, providing a moment of silence for prayer in public schools, and posting the Ten Commandments. See supra notes 31-33 and accompanying text.

84 These were the conflicting claims about the government's purposes in Aguillard, 482 U.S. at $585-94$.

85 E.g., id. at 586-87 ("While the Court is normally deferential to a State's articulation of a secular purpose, it is required that the statement of such purpose be sincere and not a sham."). 
Abortion restrictions present a different kind of problem. The relevant dispute over abortion is not about whether the government's stated secular purpose is a sham to conceal its true, religious purpose. There is general agreement that the government's purpose is to protect fetal life, based on the belief that fetuses are human beings. ${ }^{86}$ Instead, the problem is figuring out whether this goal is best understood as secular or religious. Thus, pro-choice commentators must look beyond Supreme Court secular-purpose case law to other legal (and non-legal) sources to distinguish between religious and secular purposes. The ultimate-concerns argument provides one way to fill in this gap; the faith-versus-reason argument examined in the next sub-section is another.

The legal roots of the ultimate-concerns approach lie in the Supreme Court's conscientious-objector cases, which held that religious belief includes any belief that "is sincere and meaningful" and "occupies a place in the life of its possessor parallel to that filled by the orthodox belief in God." 87 These cases involved statutory interpretation, not constitutional interpretation, and the central issues more closely resembled Free Exercise Clause problems than Establishment Clause ones. ${ }^{88}$ Nonetheless, most federal courts of appeals have applied the holdings of those cases in both Free Exercise Clause and Establishment

86 There are some scholars who dispute the government's real purpose, arguing that nobody really believes that fetuses are persons or full-fledged human beings. According to Professor Dworkin, the proposition that the fetus is a person with rights is neither secular nor religious; rather, it is obviously false, and it is not the government's real purpose. His complex argument, briefly summarized, is that virtually nobody, even religious pro-lifers, actually believes that a pre-viable fetus is a person or has any rights of its own. The real issue motivating the abortion debate is competing ideas about the intrinsic value, meaning, and sacredness of human life; yet the intrinsic value of human life is a religious question. Therefore, the government violates the Establishment Clause when it restricts abortion based on one sectarian understanding of why human life is valuable. See DwORKIN, supra note 8 , at 24-28. There are many ways to respond to this argument, and this Article provides one way: the personhood of a pre-viable fetus can be defended plausibly even using only secular modes of reasoning. See discussion infra Part III.B.

87 United States v. Seeger, 380 U.S. 163, 165-66 (1965); see also Welsh v. United States, 398 U.S. 333, 340 (1970) (holding that even a "purely ethical or moral" belief is religious if it imposes upon the individual a "duty of conscience" that parallels the "strength of traditional religious convictions"). But cf. Gillette v. United States, 401 U.S. $437,441,443,455$ (1971) (holding that the conscientious-objector exemption does not apply to a Catholic who objects to some wars (Vietnam) but not all wars).

88 The question presented for the Court in the conscientious-objector cases was the statutory definition of religion under the Selective Service Act, 50 U.S.C. $\$ 456(j)$ (1958), not the First Amendment. Nonetheless, most commentators agree that the outcome in these cases is strained as a matter of statutory interpretation, and that an evolving constitutional conception of religion is what actually produced the Court's conclusions. See, e.g., Note, Toward a Constitutional Definition of Religion, 91 HARV. L. REV. 1056, 1064 (1978) (citing Seeger, 380 U.S. at 174, 188). 
Clause contexts. These lower courts define religion to mean a "comprehensive" worldview that provides answers to "fundamental" questions about human life, communicated through hierarchical institutions, sacred texts, ritual practices, and other indicia. ${ }^{89}$

Some scholars have referred to this approach as the "ultimate concerns" definition of religion, because it identifies "religious" beliefs as whichever beliefs involve the most fundamental and all-encompassing (i.e., ultimate) concerns of the believer. ${ }^{90}$ This development in Establishment Clause doctrine closely parallels an influential trend within contemporary liberal political theory, which holds that "comprehensive" theories of morals and metaphysics (the paradigm of which is religion) are illegitimate grounds for political argument and governmental action. ${ }^{91}$ According to many prominent liberal theorists, the "constitutive political morality" of liberalism is "that political decisions must be, so far as is possible, independent of any particular conception of the good life, or of what gives value to life."92 The fundamental principle of the liberal state is that individuals should be allowed "to make the sense they can of their place in the universe" and, therefore, that the government must not attempt to "solve the final mysteries of life." 93

Numerous pro-choice commentators have applied the ultimateconcerns definition of religion and/or the closely related framework of liberal political theory to the abortion context. The most common

89 The leading judicial approaches, which share much in common, originated in Malnak v. Yogi, 592 F.2d 197, 207-10 (3d Cir. 1979) (Adams, J., concurring in the judgment), and United States v. Meyers, 906 F. Supp. 1494, 1502-04 (D. Wyo. 1995), aff'd, 95 F.3d 1475, 1482-84 (10th Cir. 1996) (adopting the district court's method for defining religion); see also Jeffrey Omar Usman, Defining Religion: The Struggle to Define Religion Under the First Amendment and the Contributions and Insights of Other Disciplines of Study Including Theology, Psychology, Sociology, the Arts, and Anthropology, 83 N.D. L. REV. 123, 173-76 (2007) (summarizing the various ways federal circuit courts have defined religion).

90 E.g., Ingber, supra note 66, at 268 (quoting Toward a Constitutional Definition of Religion, supra note 88, at 1077 n. 113).

91 Among contemporary liberal theorists, John Rawls argued that civic debate about justice should not resort to "comprehensive doctrines" about which reasonable citizens disagree. Instead, we should ground political deliberation in an "overlapping consensus" that reasonable citizens can agree upon without reference to their different comprehensive worldviews. JOHN RAWLS, POLITICAL LIBERALISM xx-xxi (1993). Although Rawls's idea has been vastly influential, many critics have argued that his version of political liberalism is not only undesirable, but also incoherent. See, e.g., John M. Breen, Neutrality in Liberal Legal Theory and Catholic Social Thought, 32 HARV. J.L. \& PUB. POL'Y 513, 552 (2009) ("Even liberal regimes inevitably make use of some theory of the good in the formulation of law, thus exposing the liberal exclusion of alternative conceptions of the good as arbitrary and unprincipled.").

92 E.g., RoNALD DWORKIN, A MATTER OF PRINCIPLE 191-92 (1985).

93 BruCE A. ACKerman, Social Justice in the Liberal State 347-48 (1980). 
argument along these lines is that concern for fetal life (and particularly the view that the fetus is a human person) is based on "[a]bstract metaphysical speculation" that is appropriate for "theology" but inappropriate in the context of democratic politics. ${ }^{94}$ Professor Ronald Dworkin sounded a variation on this theme, claiming that anti-abortion laws are unconstitutional because they require the government to take sides on several different "fundamentally" "religious" issues: "the ultimate point and value of human life," "why life has intrinsic importance," and "how that value is respected or dishonored in different circumstances." 95

\section{Faith Versus Reason}

Justice Stevens and other commentators propose a different way to fill the gap in secular-purpose case law and to bring that case law to bear against abortion restrictions. Their concern is very different from that of the ultimate-concerns commentators: they do not focus on the type of question (fundamental questions) abortion restrictions seek to answer, or the scope of the worldview (comprehensive worldviews) from which citizens derive their views about abortion. In fact, these commentators seek to provide secular answers to the exact same question that abortion opponents seek to answer: when does the fetus become a human being? ${ }^{96}$

Instead, their objection is that the pro-life answer to that question relies upon religious modes of thinking rather than rational, secular modes.97 They argue that religious beliefs derive from faith and obedience to doctrinal authority, whereas secular beliefs are the product of secular forms of reasoning, such as "logic," "history," and "shared experiences." 98 They contend that protecting pre-viable fetuses cannot be plausibly defended on the basis of secular reasoning, so governmental actions to advance that goal violate the Establishment Clause. ${ }^{99}$

\section{A Clarification}

For the sake of simplicity, this Article has referred generically to Establishment Clause objections to restrictive abortion laws. The precise

94 E.g., Simmons, Religious Liberty and Abortion Policy, supra note 8.

95 DWORKIN, supra note 8, at 164-65.

96 See, e.g., WENZ, supra note 8, at 180 ("After twenty-eight weeks . . there are grounds in secular values for attributing personhood to the fetus....").

97 See, e.g., Thornburgh v. Am. Coll. of Obstetricians \& Gynecologists, 476 U.S. 747, 778 (1986) (Stevens, J., concurring) ("I recognize that a powerful theological argument can be made for [protecting fetal life throughout pregnancy], but $I$ believe our jurisdiction is limited to the evaluation of secular state interests.").

98 Id. at 779.

99 See Webster v. Reprod. Health Servs., 492 U.S. 490, 569 (1989) (Stevens, J., concurring in part and dissenting in part). 
objection is narrower and more complicated, and I will clarify it in this sub-section. The primary complaint of commentators and the Supreme Court is about unduly burdensome abortion laws that protect pre-viable fetuses. ${ }^{100}$ Roe generally permits governmental restriction of abortion after viability, ${ }^{101}$ and Planned Parenthood of Southeastern Pennsylvania $v$. Casey even allows for the regulation of abortion prior to viability, as long as the regulations do not create an "undue burden" on the abortion right. 102 Thus, the Court distinguishes between pre-viability and postviability abortion regulation, and again between burdensome and nonburdensome pre-viability regulations.

The Establishment Clause objections reviewed in this Part draw similar distinctions. According to most of the commentators making these objections, secular goals might justify protecting fetuses once they reach approximately viability, but not before that point. The commentators differ in the reasons they give for why viability is morally significant from a secular point of view, and some believe that viability itself is less important than other fetal developments (such as sentience), which approximately coincide with viability. ${ }^{103}$ In spite of this squabble, they generally agree that the morally significant point in fetal development occurs at or about viability, and that protecting fetuses after viability, but not before, can be supported with secular justifications.

Because the Supreme Court's abortion cases also take this shapecondemning intrusive pre-viability regulations, but not regulations that protect viable fetuses - the structure of the Court's UEC, if it exists at all, should be expected to share this structural complexity. It will not categorically dismiss opposition to all abortions as religious. Instead, it will be targeted at particular reasons (state interests) for regulating abortion, recognizing some governmental purposes as legitimate and secular, but others as impermissible. With these expectations in mind, we now turn to Part II and the UEC.

100 See, e.g., id. (acknowledging a powerful state interest in viable, fully sentient fetuses, but denying a comparable secular interest for embryos). This is not uniformly true: some pro-choice commentators reject the significance of viability. See, e.g., WENZ, supra note 8 , at 181 .

101 Roe v. Wade, 410 U.S. 113, 163 (1973).

102505 U.S. 833, 876-77 (1992) (plurality opinion).

103 Compare Tribe, The Supreme Court, 1972 Term, supra note 8, at 27 (arguing that viability is intrinsically important because once a fetus can live on its own outside the womb, abortion unnecessarily kills a fetus that could just as easily be delivered and survive), with DWORKIN, supra note 8 , at 17 (arguing that approximately viability is important because the fetus develops sentience around that point in its development). 


\section{The UNDERgRound Establishment Clause}

The previous Part introduced a variety of arguments that commentators have advanced to show that restrictive abortion laws violate the Establishment Clause. This Part reveals that the Supreme Court invoked strikingly similar arguments to justify the constitutional right to abortion. These arguments constitute an underground Establishment Clause, in the sense that the Court never openly relied on the Establishment Clause as the source of its analysis. Instead, the Court purported to rely entirely on the Due Process Clause. ${ }^{104}$

Therefore, the task of this Part is to dig beneath the surface of the text and to reveal how the Court wove Establishment Clause themes into the fabric of its Due Process analysis. I trace this phenomenon from its beginnings in Roe $v$. Wade and show how the idea evolved in later cases. The Part concludes by showing how the Court's most recent abortion decision, Gonzales v. Carhart, ${ }^{105}$ represents a substantial retreat from the UEC approach to abortion rights.

\section{A. Roe v. Wade \\ 1. Background}

In Roe $v$. Wade, the Court held that the choice to obtain an abortion is a fundamental liberty protected by the Fourteenth Amendment. ${ }^{106}$ Most commentary about Roe focuses on that part of the Court's holding. ${ }^{107}$ However, finding that a particular activity is a "fundamental liberty" does not end the constitutional inquiry. Even when the Court finds that a fundamental right is at stake, the government may intrude on that right if it has a "compelling" justification for doing so. ${ }^{108}$ Justice Blackmun, writing for the Court in Roe, acknowledged that this general principle holds true in the abortion context. ${ }^{109}$ The focus of this Section, and the place where the Roe UEC reveals itself most clearly, is the second part of the Court's Due Process inquiry: whether the government has a "compelling interest" for regulating abortion that is sufficient to override the "fundamental liberty" of women to acquire an abortion.

104 See Roe, 410 U.S. at 153.

105550 U.S. 124 (2007).

106 See Roe, 410 U.S. at 153.

107 For a collection of numerous criticisms of Roe, most of which focus on the privacy/liberty holding, see Teresa Stanton Collett, Judicial Modesty and Abortion, 59 S.C. L. REV. 701, 702 n.3 (2008).

108 CHEMERINSKY, supra note 16 at 767.

109 See Roe, 410 U.S. at 155 ("Where certain 'fundamental rights' are involved, the Court has held that regulation limiting these rights may be justified only by a 'compelling state interest'...." (citations omitted)). 
The Texas government's appellate brief in Roe vigorously argued that prohibiting abortion has a compelling justification: "the fetus is a human being," and therefore the state must protect it against "arbitrary and unjustified destruction." 110 The government also advanced an even more ambitious argument: not only do legislatures have a compelling interest in protecting fetuses (which gives them constitutional permission to do so), but they also are constitutionally required by the Equal Protection Clause ${ }^{111}$ to protect unborn human lives the same as they protect other citizens. ${ }^{112}$ Blackmun acknowledged that if unborn children are "persons" for purposes of the Equal Protection Clause, the case for abortion rights "collapses."113

\section{The State's Argument that Fetuses Are "Persons" Under the Fourteenth Amendment}

Blackmun replied to these two arguments separately and distinctly. He directly rejected the Texas government's Equal Protection argument, holding that a fetus is not a "person" under the Fourteenth Amendment. ${ }^{114} \mathrm{He}$ argued that the Amendment's framers did not intend for it to apply to unborn persons, and that in other places where the Constitution speaks of "persons," the term is expressly limited to (or only makes sense in application to) born persons. ${ }^{115}$ No Supreme Court justice has ever disagreed with this part of the holding in Roe, ${ }^{116}$ although several scholars have done so powerfully. ${ }^{117}$

110 Brief for Appellee, supra note 18, at 9.

111 U.S. CONST. amend. XIV, § 1 ("[Nor] shall any State . . . deny to any person within its jurisdiction the equal protection of the laws.").

112 See Brief for Appellee, supra note 18, at 56. Several amici advanced this point in greater detail. See, e.g., Brief of Ams. United for Life, Amicus Curiae, In Support of Appellee at 4-10, Roe, 410 U.S. 113 (No. 70-18).

113 Roe, 410 U.S. at 156.

114 Id. at 157.

115 Id. at $157-58$.

116 See Planned Parenthood of Southeastern Pennsylvania v. Casey, 505 U.S. 833, 913 (1992) (Stevens, J., concurring in part and dissenting in part).

117 See, e.g., James S. Witherspoon, Reexamining Roe: Nineteenth-Century Abortion Statutes and the Fourteenth Amendment, 17 ST. MARY'S L.J. 29, 31 (1985) (arguing for fetal personhood under the Fourteenth Amendment on historical grounds); Charles I. Lugosi, Conforming to the Rule of Law: When Person and Human Being Finally Mean the Same Thing in Fourteenth Amendment Jurisprudence, 22 IssUES L. \& MED. 119, 119-22 (2006) (arguing for fetal personhood primarily based on egalitarian political theory). However, most scholars support Blackmun's conclusion that fetuses are not "persons" under the Fourteenth Amendment. See Jack M. Balkin, Abortion and Original Meaning, 24 ConST. COMMENT. 291, 338 (2007). 


\section{The State's Scientific/Philosophical Argument That Fetuses Are Persons}

Blackmun's refusal to recognize fetuses as "persons" under the Fourteenth Amendment was based entirely on technical considerations, such as the text, structure, and (to a lesser extent) history of that constitutional provision. ${ }^{118} \mathrm{He}$ did not argue that fetuses are actually non-persons, nor did he apply the scientific, philosophical, or intuitionbased reasoning that would be necessary for determining whether fetuses are actually persons.

Thus, Blackmun rightly acknowledged that his resolution of the Equal Protection issue "does not of itself fully answer" the State's other argument 119 : that scientific and philosophical reasoning proves the humanity and personhood of fetuses, and therefore that the State has a compelling justification for protecting them against abortion. ${ }^{120}$ The humanity of fetal life, if it were established as a fact, would supply the State with constitutional permission to restrict abortion, ${ }^{121}$ even if the Equal Protection Clause does not require that it do so.

How, then, did Blackmun answer the State's scientific and philosophical arguments that fetuses are human beings? As it turns out, he refused to give an answer: "We need not resolve the difficult question of when life begins." ${ }^{122}$ It is here, in his refusal to answer the State's most pressing defense, that the UEC comes into play.

However, it will take some work to prove my claim, because the surrounding text, where Blackmun attempts to justify his approach, is riddled with ambiguity. The next sub-section will propose and defend my UEC interpretation of the text; afterwards, I will address other, nonUEC explanations for Blackmun's method, ultimately concluding that the UEC is an essential part of the explanation (but not the entire explanation) for why Blackmun rejects the State's compelling interest in protecting fetal life.

\section{Establishment Clause Themes in Roe}

The core justification that Blackmun provided for refusing to say when life begins is, implicitly, an Establishment Clause argument that blends together the three objections introduced in Part I. He emphasized the religion-related divisions surrounding the issue of fetal personhood (a political-divisiveness argument), the profound ethical and

118 Roe, 410 U.S. at 157.

119 Id. at 159.

120 See Brief for Appellee, supra note 18, at 29-57.

121 Compare CHEMERINSKY, supra note 16, at 767, with Roe, 410 U.S. at 155 ("Where certain 'fundamental rights' are involved, the Court has held that regulation limiting these rights may be justified only by a 'compelling state interest' . . ." (citations omitted)).

122 Roe, 410 U.S. at 159. 
anthropological content of that issue (an ultimate-concerns argument) and, to a lesser extent, the impossibility of resolving it with secular methods of reasoning (a faith-versus-reason argument). ${ }^{123}$

Immediately after declaring that he "need not resolve" the question, Blackmun explained that " $[\mathrm{w}]$ hen those trained in the respective disciplines of medicine, philosophy, and theology are unable to arrive at any consensus, the judiciary, at this point in the development of man's knowledge, is not in a position to speculate as to the answer." ${ }^{124} \mathrm{He}$ further contended that the "wide divergence of thinking" and the "sensitive and difficult" nature of the question were "sufficient" to justify his refusal to give an answer. ${ }^{125}$

Blackmun did not spell out precisely why he found these divisions sufficient to reject the State's assertion that fetuses are human beings. The fact that he discussed divisions within the discipline of medicine, and not only in those of theology and philosophy, tends to support a nonUEC reading of the text (which I will explore below). However, his references to the sensitive nature of the fetal-personhood question and the impossibility of addressing it with knowledge rather than speculation are central rhetorical and conceptual themes in the ultimateconcerns and faith-versus-reason arguments about abortion. ${ }^{126}$ These themes are less plausibly explained by the non-UEC interpretation that I will discuss later on.

More importantly, although Blackmun did briefly discuss divisions of opinion among scientists, he devoted the bulk of the section to cataloguing divisions among religions or quasi-religious philosophical systems. He described the view of the ancient Stoics, most Jews, and many Protestant groups that life begins at live birth; the Aristotelian and medieval Catholic view that ensoulment occurs at some point during pregnancy; the modern Catholic view that life begins at conception; and the varied opinions of scientists, some saying that life begins at conception, others at viability, and still others at birth. ${ }^{127}$

123 See generally supra Part I.B (describing the political divisiveness, ultimate concerns, and faith versus reason arguments against abortion restrictions).

124 Roe, 410 U.S. at 159.

125 Id. at 160.

126 Id. at 159, 160 (citing Motion of American Ethical Union et al. for Leave to file a Brief as Amici Curiae in Support of the Appellant's Position, Doe v. Bolton, 410 U.S. 179 (1973) (No. 70-40), and Roe, 410 U.S. 113 (No. 70-18) [hereinafter Motion of American Ethical Union et al.]; LUDWIG EDELSTEIN, THE HiPPOCRATIC OATH: TEXT, TransLation, AND INTERPRETATION 16 (1943); DORLAND'S ILLUSTRATED MEDICAL DICTIONARY 1689 (24th ed. 1965); LAWRENCE LADER, ABORTION, 97-99 (1966); DAVID M. FELDMAN, BIRTH CONTROL IN JEWISH LAW 251-94 (1968); L. M. HELlmaN \& J. A. PRITCHARD, Williams Obstetrics 493 (14th ed. 1971)).

127 See id. at $160-61$. 
Several of the historical sources that Blackmun cited in this paragraph provide further insight into why he found the divergence of opinion among religions to be significant. To begin with, consider Lawrence Lader. In a 1966 book entitled Abortion, Lader argued that "abortion forces us to face absolutes that intrude on religious dogma," and that "dogma becomes political where it has the power to make its votes felt." 128 The chapter of the book that Blackmun relied upon in this section of Roe sought to describe (and critically evaluate) Catholic, Jewish, and Protestant views about abortion. ${ }^{129}$ According to Lader, the "conflicting positions of our three major faiths on the beginnings of life" enable us to see how "U.S. abortion laws" are "linked inextricably" with the "religious" question of when a fetus "become[s] a human being, infused with a rational soul." 130 Specifically, he concluded that the Catholic view about fetal life has "maintained an inexplicable influence" over the development of Protestant moral theology and American abortion law. ${ }^{131}$

Furthermore, to support his observation that "organized [Protestant] groups that have taken a formal position on the abortion issue have generally regarded abortion as a matter for the conscience of the individual and her family," Blackmun cited an amicus brief written by a variety of religious and humanist organizations. ${ }^{132}$ The central contention of the brief is that abortion is a "matter of individual conscience to be exercised within the context of one's own faith," "free of unwarranted governmental interference." 133 These amici saw the intrusion of abortion restrictions upon "freedom of conscience" not only as a Free Exercise Clause violation, but also as a breach of the Establishment Clause. ${ }^{134}$ The Establishment Clause problem consists in "the fact that religious beliefs [underlie] the retention of abortion laws," because such laws "in effect codif[y] 'the official Roman Catholic view' that assigns an undefined value to foetal life from the moment of conception." 135

128 LAWRENCE LADER, ABORTION 2 (1966).

129 Blackmun cited Lader twice in the paragraph of Roe on which $\mathrm{I}$ am currently focusing, see Roe, 410 U.S. at 160 n. 57-58, and numerous times elsewhere in the opinion, see id. at 130 n.9, 132 n.17, n.21, 135 n.26, 139 n.33, 149 n.44.

130 LADER, supra note 128 , at 94.

131 Id. at 101-02.

132 Roe, 410 U.S. at 160 (citing Motion of American Ethical Union et al. supra note 126).

133 Motion of American Ethical Union et al. supra note 126 at 4-5.

134 Id. at 34 (quoting Paul J. Mishkin, The Supreme Court, 1964 Term, 79

HARV. L. REV. 56, 162, 165 (1965)).

135 Id. at 32-33 (quoting Rosen v. Louisiana Bd. of Med. Exam'rs, 318 F. Supp. 1217, 1223 \& n.2, 1231 n.18 (E.D. La. 1970), vacated, 412 U.S. 902 (1973)). 
To be clear, Blackmun did not directly quote these passages from the amicus brief or Lader's book. He cited those sources for the purpose of showing the wide divergence of religious opinion about fetal life, without explaining why he saw that divergence as significant. His sources are more forthright about the moral and legal significance of the wide divergence of opinion on abortion: for them, the divergence reveals that American abortion laws are "linked inextricably" to religious views about the fetus ${ }^{136}$ and therefore violate the Establishment Clause. ${ }^{137}$ These passages provide clues as to Blackmun's serious, yet undisclosed, reason for emphasizing religious divisions about fetal life.

Finally, Roe's refusal to say when life begins should be read in conjunction with the introduction to the opinion, which reveals Blackmun's deep concern about the religion-related political divisions and the ultimate ethical/religious considerations associated with abortion. ${ }^{138}$ After briefly stating the procedural posture of the case, Blackmun opened the opinion by expressing his "awareness of the sensitive and emotional nature of the abortion controversy, of the vigorous opposing views, ... . and of the deep and seemingly absolute convictions that the subject inspires." 139 Moreover, he observed that a person's "philosophy," "experiences," "religious training," and "moral standards" all shape our views about abortion. ${ }^{140}$

$\mathrm{He}$ contrasted these problematic and divisive dimensions of the abortion debate from what the Court must do: "Our task, of course, is to resolve the issue by constitutional measurement, free of emotion and of predilection." 141 He elaborated on this aspect of the judicial role by quoting one of the famous passages from Justice Oliver Wendell Holmes's dissent in Lochner $v$. New York. ${ }^{142}$ In the quoted passage, Holmes argued that "[the Constitution] is made for people of fundamentally differing views," and therefore that justices should bracket their personal views about morality and politics when making judgments about the meaning of the Constitution. ${ }^{143}$

This introduction communicates two ideas with clarity and urgency. First, Blackmun was deeply worried about the deep and sensitive

\footnotetext{
136 LADER, supra note 128 , at 94.

137 See Motion of American Ethical Union et al., supra note 126, at 31-34.

138 Roe v. Wade, 410 U.S. 113, 116 (1973).

139 Id.

$140 \mathrm{Id}$.

141 Id.

142198 U.S. 45 (1905).

143 See Roe, 410 U.S. at 117 (quoting Lochner v. New York, 198 U.S. 45, 76 (1905) (Holmes, J., dissenting)). For a discussion of the extraordinary influence that the story of Lochner and its demise have had for future generations of lawyers and judges, see Cass $R$. Sunstein, Lochner's Legacy, 87 CoLUM. L. REV. 873, 873-74 (1987).
} 
religious and ethical divisions about abortion in American society. Consequently, he sought to ameliorate those divisions by exiling them from the domain of constitutional law and politics, which must be "free of emotion and of predilection."144 This feature of Blackmun's argument parallels the political divisiveness argument from the Establishment Clause context.

Second, he emphasized that people's views about abortion are formed by our most fundamental concerns in life: “One's philosophy, one's experiences, one's exposure to the raw edges of human existence, one's religious training, one's attitudes toward life and family and their values, and the moral standards one establishes and seeks to observe." 145 These conceptual concerns and rhetorical emphases directly parallel those of the ultimate concerns argument against abortion restrictions.

\section{An Alternative Interpretation of Roe}

This sub-section presents and evaluates another potential interpretation-a non-UEC reading-of the texts from Roe discussed above. For the non-UEC interpretation, the divisions and controversy surrounding the question of when life begins has little to do with the Establishment Clause, and everything to do with the government's burden of proof. Under the Court's normal method in Due Process cases, whenever the government intrudes on fundamental liberties (recall that Roe had already held that the abortion right is a fundamental one ${ }^{146}$ ), it bears the difficult burden of providing a compelling justification for depriving that liberty. ${ }^{147}$ Widespread disagreement about when life begins tends to show that the State's interest is not entirely convincing and therefore not compelling. Thus, the non-UEC interpretation would suggest that Blackmun was doing precisely what he purported to do: applying the Court's usual substantive due process methodology to the problem of abortion.

There is considerable textual support for this burden-of-proof interpretation, and it does appear to be one of the underlying reasons why Blackmun considered divisions of opinion to be so important. In particular, the burden of proof interpretation helps to explain why Blackmun discussed scientific disagreements about when life begins and, in the following paragraph, the variety of legal approaches to the status

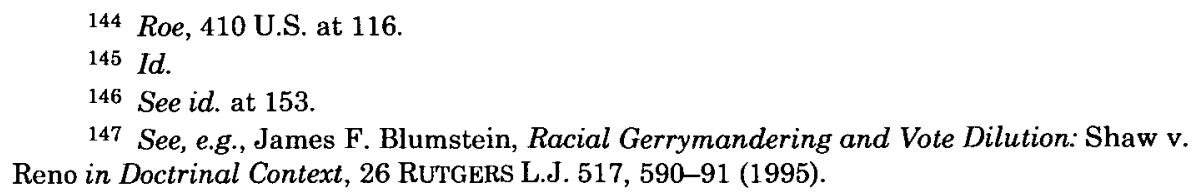


of fetal life. ${ }^{148}$ These scientific and legal disagreements tend to show that the interest claimed by the State is not yet firmly established within relevant domains of knowledge.

However, taken alone, this reading of Roe leaves too much unexplained. In the relevant textual passages, Blackmun did not focus his attention solely on disagreements about when life begins within the secular disciplines. On the contrary, he primarily stressed the contents of, and disagreements among, religious viewpoints about fetal life. Unlike scientific and philosophical disagreement about when life begins, the fact that religions disagree about that question has little relevance to the State's burden of proving a compelling (secular) interest in protecting fetal life. Blackmun's emphasis on religious disagreements, therefore, is best understood as suggesting that religious purposes, and not secular ones, lie underneath anti-abortion laws.

Furthermore, Blackmun's references to (among other things) the "sensitive" nature of the question when life begins and the "vigorous opposing views" and "seemingly absolute convictions" that people hold about abortion reveal his anxiety about the corrosive social and political effects of the divisions surrounding abortion. ${ }^{149}$ By revolving the introductory section of his opinion around these themes, Blackmun indicated that the management and amelioration of religiously charged political disagreement was one of the central challenges presented by the case and a primary goal that he sought to achieve in resolving it the way he did. These concerns have little to do with the State's burden of proof, and are much better explained by the UEC interpretation of Roe.

\section{The Beginnings of a Contradiction}

The previous discussion explains why the Court refused to say when life begins and, by doing so, rejected the government's interest in protecting fetal life against homicide. Yet Blackmun did not reject all governmental reasons for restricting abortion: he recognized the "less rigid claim" that the state may protect the "potential life" of the fetus. ${ }^{150}$ This sub-section explores Blackmun's potential-life concept and shows how it relates to the UEC.

148 See Roe, 410 U.S. at 160-62 (citing Motion of American Ethical Union et al. supra note 126; LUDWIG EDELSTEIN, THE HIPPOCRATIC OATH: TEXT, TRANSLATION, AND INTERPRETATION 16 (1943); FOWLER V. HARPER \& FLEMINGS JAMES, JR., THE LAW OF TORTS 1028-31 (1956); DORLAND's ILLUSTRATED MEDICAL DICTIONARY 1689 (24 th $^{\text {ed. }} 1965$ ); LAWRENCE LAder, ABORTION, 97-99 (1966); DAVId M. FELdMAN, BiRTH CONTROL IN Jewish LaW 251-94 (1968); L. M. Hellman \& J. A. Pritchard, Willilams Obstetrics 493

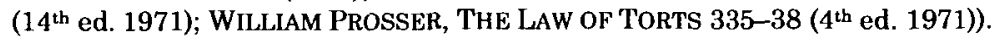

149 Id. at 116.

150 Id. at 150. 
Potential life-unlike actual life-is not a strong enough reason to ban abortion throughout all nine months of pregnancy. Nonetheless, according to Blackmun, the government's interest in potential life grows stronger as the fetus develops, and at the point of viability (approximately the third trimester), the interest in potential life becomes "compelling." From that point on, Roe allows the government to prohibit abortion, except to protect the mother's life or health. ${ }^{151}$

At first glance, recognizing an interest in potential life seems to avoid the problems Blackmun found with the State's asserted interest in actual life. Unlike the disputed question of when life begins, everyone can agree, at the very least, that potential life is present throughout all of pregnancy: the embryo or fetus, whatever it might be currently ("person" or not), it will indisputably become what we all recognize as human life unless it dies. The potential-life concept, therefore, enabled Blackmun to recognize some sort of state interest in the fetus without appearing to engage in controversial metaphysical or religious speculation about when life begins.

However, this first appearance is deceiving. Although everyone agrees that potential life exists throughout pregnancy, people do not agree about why, how much, or when we should value potential life. In fact, if the potential life is not already, in some sense, an actual life, it is not clear why we should value it at all. Given the ambiguous, and probably empty, value of potential life, we should expect that people who believe the fetus is an actual human life will place a high value on its socalled potential life, and people who think otherwise will place little or no value on the fetus's potential. ${ }^{152}$

For Blackmun, the potential life of the developing fetus becomes valuable enough for the government to protect it at the point of viability. ${ }^{153} \mathrm{He}$ provided no justification for selecting viability as the crucial moment in fetal development, apart from a brief explanation that is nothing more than a tautology. ${ }^{154}$ Nor could he provide a substantive

151 Id. at $162-64$.

152 See Jed Rubenfeld, On the Legal Status of the Proposition that "Life Begins at Conception," 43 STAN. L. REV. 599, 600 (1991) ("If the fetus is considered solely as a 'potential' person, no case for a compelling state interest can be made without covertly treating this supposed 'potentiality' as an actuality ....").

153 See Roe, 410 U.S. at 163.

154 The sole justification Blackmun provided for selecting viability is the following: "[T]he 'compelling' point is at viability. This is so because the fetus then presumably has the capability of meaningful life outside the mother's womb. State regulation protective of fetal life after viability thus has both logical and biological justifications." Id. This argument tautologically defends viability by defining it; other than providing a definition of fetal viability (i.e., the point where the fetus has 'capability of meaningful life outside the mother's womb'), Blackmun makes no effort to show why viability, defined in this way, is morally significant. See John Hart Ely, The Wages of Crying Wolf: A Comment on Roe v. 
justification for selecting viability, because any such justification would make it obvious that Blackmun was effectively answering the forbidden question of when life begins, or, at least, when life becomes valuable. It is no coincidence that (approximately) viability is the point where most liberal commentators say that the fetus becomes an actual human being, or, more precisely, when it becomes a morally significant entity possessing rights apart from its mother. ${ }^{155}$ This non-coincidence strongly suggests that Blackmun was using potential life as a cover for his judgment that the fetus's humanity becomes actual or morally relevant at viability.

Thus, despite Blackmun's effort to tell us that he "need not resolve the difficult question of when life begins," 156 and to justify that claim by using the UEC, he effectively did make a decision about when human life begins. This decision, like the UEC itself, happened underground: under the façade of the potential-life concept.

Thus, two features of Blackmun's argument-the UEC and potential life-are essential to the holding and scope of Roe, yet they are in severe tension with each other. In the $1980 \mathrm{~s}$, this tension would be exploited by abortion opponents on the Court, who embraced and expanded the potential-life concept as a way to turn Roe against itself. Before I address those arguments (in Part II.C), I must address a case that the Court decided in the period between Roe and the jurisprudential counterattack that began in the mid-1980s. That case, which further defines the contours of the UEC, is the subject of the next Section.

\section{B. Harris v. McCrae and the Complex Structure of the Underground Establishment Clause}

Harris v. McCrae is crucial for understanding the Roe UEC, because the Court was presented with-and rejected-a direct Establishment Clause challenge to a routinely re-enacted abortion restriction called the Hyde Amendment. ${ }^{157}$ This sub-section demonstrates that Harris does not contradict the Roe UEC, but instead clarifies some of its complex features.

The Hyde Amendment generally prohibits the use of federal Medicaid funds to reimburse abortions. ${ }^{158}$ The challengers argued (among other things) that the legislation violates the Establishment

Wade, 82 YALE L.J. 920, 924 (1973) ("[T]'he Court's defense seems to mistake a definition for a syllogism.").

155 See supra note 103 and accompanying text.

156 Roe, 410 U.S. at 159.

157448 U.S. 297, 300-03 (1980) (describing the "various versions of the Hyde Amendment" that were at issue in the litigation).

158 See id. at 302 (citing Pub. L. 96-123, § 109, 93 Stat. 926 (1979)). 
Clause because it privileges certain religious views over others, ${ }^{159}$ lacks a secular purpose, ${ }^{160}$ and sharpens religious divisions ${ }^{161}$ that threaten the "fabric of our society." 162 The district court had given these arguments extensive treatment in an unusually lengthy opinion, ${ }^{163}$ ultimately rejecting them. ${ }^{164}$

The Supreme Court rejected the Establishment Clause challenge in a single paragraph. ${ }^{165}$ A majority of the Court apparently considered the issue an easy one, and none of the dissenters openly challenged this part of the majority opinion. ${ }^{166}$ The Court recognized that disfavoring abortion is consistent with the views of some religious groups and not others (the factual basis for the political-divisiveness argument), but emphasized that this alone does not make the legislation unconstitutional. ${ }^{167}$ According to the Court, abortion restrictions reflect not only religious values, but also secular ones: "The Hyde Amendment . . . is as much a reflection of 'traditionalist' values towards abortion, as it is an embodiment of the views of any particular religion." 168

The Court's cursory treatment of the issue is rife with ambiguity: what are the traditionalist values the Court refers to, and why are they secular rather than religious? In context, the Court appears to mean two things. First, the Court's reference to traditionalist values is drawn directly from the district court's opinion, and the district court meant this: anti-abortion values are not necessarily religious because they are

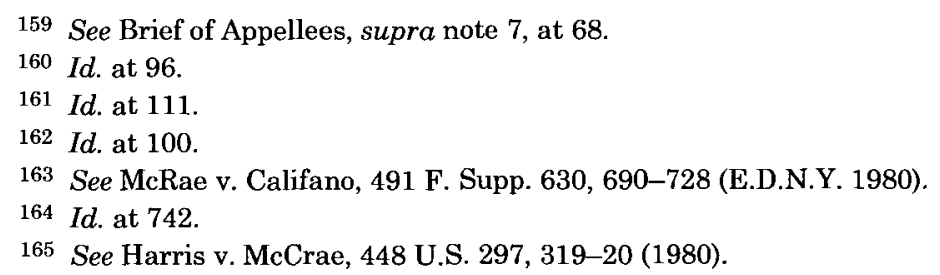

166 They did not say whether they agree with the majority's Establishment Clause holding; they did not openly reject it. However, they do use strong UEC language in the course of their Due Process and Equal Protection analyses. See id. at 332 (Brennan, J., dissenting) ("TT] he Hyde Amendment is a transparent attempt by the Legislative Branch to impose the political majority's judgment of the morally acceptable and socially desirable preference on a sensitive and intimate decision that the Constitution entrusts to the individual."); id. (lamenting the "encroachments of state-mandated morality"); id. at 348 (Blackmun, J., dissenting) ("[T]he Government "punitively impresses upon a needy minority its own concepts of the socially desirable, the publicly acceptable, and the morally sound." (citation omitted)).

167 Id. at 319 ("[D] does not follow that a statute violates the Establishment Clause because it "happens to coincide or harmonize with the tenets of some or all religions." (quoting McGowan v. Maryland, 366 U.S. 420, 442 (1961))); id. at 319-20 ("[T]he fact that the funding restrictions in the Hyde Amendment may coincide with the religious tenets of the Roman Catholic Church does not, without more, contravene the Establishment Clause.").

168 Id. at 319 (citing Califano, 491 F. Supp. at 741; Roe v. Wade, 410 U.S. 113, 138$41(1973))$. 
not held exclusively by one particular religious group, but cut across many different group boundaries. ${ }^{169}$

Second, in other parts of the Harris opinion, the Court emphasized that Roe only forbids the government from criminalizing or otherwise penalizing the abortion choice; Roe does not say that the government has to treat abortion just like any other choice. ${ }^{170}$ The government is allowed to make "a value judgment favoring childbirth over abortion," and it may "implement $[$ that judgment" by using its funds to support birth and not abortion. ${ }^{171}$ According to Harris, Roe allows the government to embrace traditionalist values that favor childbirth, as long as it does not intrude on liberty by forcing women not to get abortions. ${ }^{172}$

If the Establishment Clause categorically forbade the government from making any value judgments about abortion, the Court's analysis would be obviously wrong. Any governmental action expressing a preference for childbirth over abortion-not just coercive measures, like criminal penalties-would be unconstitutional. Does this mean that Harris signals a retreat from the UEC framework of Roe?

This conclusion is not necessary, because the Roe UEC can be reconciled with Harris. As the previous Section demonstrated, the Roe UEC took aim at situations where the government effectively declares when life begins by protecting fetuses against abortion to the same extent that it protects born human beings against homicide. Roe did not, however, condemn all governmental interventions on behalf of fetuses: it recognized the government's legitimate and secular interest ("legitimate," but not "compelling" until the point of viability) in protecting potential human life. ${ }^{173}$

Likewise, when the Harris Court approved what it calls traditionalist values, it was not referring to a governmental determination of when life begins. In Harris (unlike in Roe), the government did not need to provide a compelling interest, but only a legitimate one. Harris held that the Hyde Amendment-which refuses to pay for abortion with government money, but also refrains from

169 See Califano, 491 F. Supp. at 741 ("While Roe v. Wade argues for the measures" invalidity under the Fifth Amendment at least, it does not make the enactments any less secular in their legislative purpose. On its face such legislation, marking explicit disapproval of abortion in most cases, reflects a general and long held social view . . .."). The Supreme Court's majority opinion also hints in this direction by citing Roe, 410 U.S. at 138-41, which describes America's strong historical opposition to abortion in the nineteenth and early twentieth centuries. See Harris, 448 U.S. at 319.

170 Harris, 448 U.S. at 314-15 (quoting Maher v. Roe, 432 U.S. 464, 474 (1977)).

171 Id. at 314 (quoting Maher v. Roe, 432 U.S. 464, 474 (1977)).

172 See supra notes 167-168- and accompanying text.

173 See supra Part II.A.6. 
penalizing abortion-does not violate the right to abortion. ${ }^{174} \mathrm{By}$ not violating a fundamental right, the government never faced the burden of providing a compelling justification. Thus, the government never needed to take a position on the religiously divisive question of when life begins; it could justify itself on the basis of the less compelling, but also less controversial, preference for childbirth over abortion. ${ }^{175}$

Thus, much like the Establishment Clause arguments about abortion reviewed in Part $\mathrm{I},{ }^{176}$ the Roe UEC, as clarified in Harris, is structurally complex. It does not reflexively condemn every possible method the government might use, or rationale it might have, for objecting to abortion. Instead, the UEC targets clear attempts by the government to answer the question of when life begins by protecting non-viable fetuses against abortion as though they were already fullfledged human persons. Harris, by permitting the government to favor childbirth over abortion in ways that fall short of protecting fetuses like full human beings, clarifies rather than contradicts the Roe UEC.

\section{The Potential-Life Dilemma}

After Harris, the next chronological step in the evolution of the Supreme Court's abortion-rights UEC came in the mid-to-late-1980s, when the conservative justices on the Court reclaimed the potential-life concept from Roe and expanded it in ways that threatened to undermine the UEC. This Section traces the attempt by anti-abortion members of the Court to destroy the Roe UEC from within, and how Justice Stevens developed his explicit Establishment Clause case for abortion rights in response to the conservative critique. I conclude by documenting the approving reaction that Stevens's argument received from several major proponents of the Roe UEC, including Blackmun himself.

\section{Recap of the Tension Between "Potential Life" and the Roe UEC}

As I explained previously, Roe's UEC suffered from a central contradiction from the beginning. Roe held that the government could not answer the question of when life begins, declare fetuses to be human lives, and protect them accordingly by banning abortion. Instead, the Court recognized the validity of a lesser state interest: the interest in promoting potential life. This alternative appeared to avoid the controversy surrounding the question of when life begins, because everyone can agree that an embryo or a fetus is, at the very least, potentially a human life. ${ }^{177}$

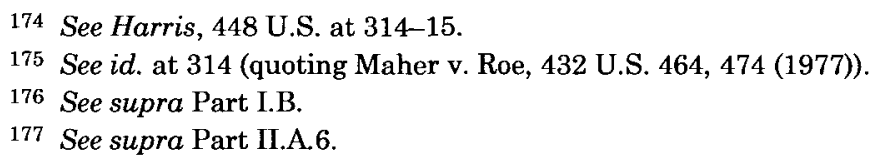


Yet the problem resurfaces when we try to define why, to what extent, and when potential life is valuable. Blackmun said that viability marks the point where potential life becomes valuable enough to constitute a compelling state interest. Without saying so explicitly, Blackmun effectively joined the chorus of liberal scholars who argue that viability (or approximately viability) marks the beginning of human personhood. Thus, his (underground) pronouncement that fetuses become valuable members of the human community at the point of viability is in direct tension with the Roe UEC. ${ }^{178}$

\section{The Collapse of the Potential-Life Framework}

The contradictions within Blackmun's potential-life framework left Roe vulnerable to attack from multiple angles. One possible line of attack was to agree with Blackmun that potential life is a compelling state interest, but stretch the meaning of potential life to include all fetal and embryonic life. Potential life is an inherently expansive concept: even if actual human personhood does not begin until approximately viability (as Blackmun implied), the newly conceived embryo (and probably even sperm and eggs before conception) undoubtedly qualifies as a potential human life. ${ }^{179}$ Thus, a small and logical adjustment to Roe-extending the post-viability compelling interest in potential life to cover all post-conception potential lives-would justify comprehensive prohibition of abortion, completely erasing the right recognized in Roe. ${ }^{180}$

This simple but devastating modification to Roe was first proposed by a member of the Court during the early 1980s, and it quickly gained momentum and became one of the most important threats to the constitutional right to abortion. In Akron v. Akron Center for Reproductive Health, Justice O'Connor argued in dissent that "potential life is no less potential in the first weeks of pregnancy than it is at viability or afterward. At any stage in pregnancy, there is the potential for human life."181 O'Connor embraced and extended the concept of potential life, arguing that the state has a "compelling" interest in protecting potential human life "throughout the pregnancy." 182

178 See id.

179 See, e.g., Rubenfeld, supra note 152, at 613 ("'[P]otential life' does not begin at conception any more than it begins at viability. Accordingly, if the state has a compelling interest in protecting 'potential life,' profound consequences follow. A state could forbid not only abortion, but contraception as well.").

180 See id. at 600 ("By Roe's own logic, to hold that the state's interest in protecting 'potential life' exists equally throughout pregnancy is to hold that states may bar abortion completely.").

181462 U.S. 416, 461 (1983) (O'Connor, J., dissenting).

182 Id. 
Justices White and Rehnquist picked up her argument three years later, ${ }^{183}$ and in 1989, Justice Kennedy signed on by joining Rehnquist's plurality opinion in Webster $v$. Reproductive Health Services. ${ }^{184}$ If five justices had embraced the argument in Webster, then the Court would have given state legislatures a compelling justification for prohibiting abortion both pre- and post-viability. That would have signaled the end of Roe. ${ }^{185}$

Proponents of the Roe UEC could not respond to this line of reasoning. In fact, the UEC necessarily disarmed them of any weapons they might otherwise have used to defend themselves. Any serious effort to distinguish some potential lives (pre-viable ones) from others (postviable ones) would not truly be about potential life. Rather, such efforts reflect judgments about how much the potential life resembles an actual life. But resolving what constitutes actual life (when life begins) is the very thing that Roe's UEC forbids.

\section{Justice Stevens's Solution}

Justice Stevens developed one solution to the dilemma, but, as this sub-section shows, his proposal abandons important elements of Roe's UEC. In Thornburgh v. American College of Obstetricians and Gynecologists, ${ }^{186}$ he began to develop his above-ground Establishment Clause argument as a response to the conservative justices' expansion of the potential-life concept. Specifically, he was responding to Justice White, who reasoned that because an embryo is just as much a

183 Thornburgh v. American Coll. of Obstetricians \& Gynecologists, 476 U.S. 747, 785, 794-95 (1986) (White, J., dissenting).

184492 U.S. 490, 498-99, 519 (1989) (opinion of Rehnquist, J., joined by Justices White and Kennedy) ("[W]e do not see why the State's interest in protecting potential human life should come into existence only at the point of viability . . . "); see id. at 532 (Scalia, J., concurring in part and concurring in the judgment) (arguing that Chief Justice Rehnquist's opinion "effectively would overrule Roe $v$. Wade," and that he agrees this "should be done, but . . . more explicitly"). Justice O'Connor, who had first introduced the argument in Akron, did not advance-or deny-it in Webster because she believed the case could be resolved on other grounds. See id. at 522, 525 (O'Connor, J., concurring in part and concurring in the judgment) ("I do not understand these viability testing requirements to conflict with any of the Court's past decisions concerning state regulation of abortion. Therefore, there is no necessity to accept the State's invitation to reexamine the constitutional validity of Roe $v$. Wade."). If she had reiterated her Akron view, then the Webster Court would have had a five-justice majority for the view that the state interest in potential life is compelling throughout pregnancy.

185 See, e.g., id. at 532 (Scalia, J., concurring in part and concurring in the judgment); id. at 555 (Blackmun, J., dissenting) (arguing that the plurality opinion would effectively overrule Roe because if "the State's interest in potential life is compelling as of the moment of conception," then "every hindrance to a woman's ability to obtain an abortion must be 'permissible").

186 Thornburgh, 476 U.S. at 778 (Stevens, J., concurring). 
"potential" life as a viable fetus, the government's interest is just as compelling at conception as it is in late pregnancy. ${ }^{187}$

Stevens replied that there may be a "powerful theological argument" for the religious view that embryonic life and fetal life are equally valuable. ${ }^{188}$ Yet, according to Stevens, when we set aside these impermissible "theological" considerations, it is "obvious" that the interest in protecting unborn life "increases progressively and dramatically as the organism's capacity to feel pain, to experience pleasure, to survive, and to react to its surroundings increases day by day." 189 Judged only by secular standards, "there is a fundamental and well-recognized difference between a fetus and a human being." 190 This distinction is supported "not only by logic, but also by history and by our shared experiences." 191

Three features of Stevens's argument are important for our purposes. First, he made a much sharper and more explicit distinction between the religious and the secular than Roe had done. He brought the Establishment Clause argument above ground. This feature was to become even clearer three years later in Webster, where he explicitly used the Establishment Clause to strike down a legislative declaration that human life begins at conception. ${ }^{192}$

Second, he circumnavigated the potential-life dilemma posed by Justice White, but only by abandoning Roe's agnosticism about when human life begins. According to Roe's political-divisiveness and ultimateconcerns UEC, the Court (and the legislature) must avoid answering the controversial, quasi-religious question of when human life begins. ${ }^{193} \mathrm{By}$ contrast, Stevens gave a direct, secular answer to the question: "there is a fundamental and well-recognized difference between a fetus and a human being."194

Third, Stevens used a faith-versus-reason type of Establishment Clause argument, which played a role, but not a prominent one, in Roe. ${ }^{195}$ For him, the question of when life begins is not an inherently religious question; some ways of answering it are religious, but other ways are secular. Secular reasoning-"logic," "history," and "shared

187 Id. at $775-76$

188 Id. at 778 (emphasis added).

189 Id. at $778-79$.

190 Id. at 779.

191 Id.; see Roe v. Wade, 410 U.S. 113, 130-33 (1973).

192 See Webster v. Reprod. Health Servs., 492 U.S. 490, 560, 571-72 (1989) (Stevens, $\mathrm{J}$., concurring in part and dissenting in part).

193 See infra Part III.A.

194 See Thornburgh, 476 U.S. at 779 (Stevens, J., concurring).

195 For a more extensive discussion of the faith-versus-reason Establishment Clause argument against abortion restrictions, see generally supra Part II.C.3, and infra Part IV. 
experiences"-tells us that post-viable fetuses are persons, and previable ones are not. ${ }^{196}$

\section{Reactions from the Other Liberal Justices}

The other liberal justices on the Court have taken a cautiously approving stance toward Stevens's argument. None of them formally signed on to the three opinions in which he articulated his Establishment Clause position. ${ }^{197}$

However, three liberal justices (Blackmun, Brennan, and Marshall), in an opinion written by Blackmun, quoted and embraced Stevens's argument from Thornburgh. Confronted with the expansion of potential life to cover all nine months of pregnancy by the conservative Webster plurality, Blackmun said that "I cannot improve upon what JUSTICE STEVENS has written," and he proceeded to quote, in full, the relevant parts of Stevens's analysis. ${ }^{198}$ Immediately following the quote, Blackmun provided a "see also" citation to Roe, suggesting that he viewed Roe as complementary with and similar to Stevens's Establishment Clause analysis. ${ }^{199}$

In his Webster opinion, Blackmun did not specifically cite the Establishment Clause, just as Stevens had not in Thornburgh. Yet three years later, in his partial concurring opinion in Planned Parenthood of Southeastern Pennsylvania v. Casey, Blackmun again cited the relevant part of Stevens's Thornburgh opinion. On that occasion, he openly invoked the Establishment Clause against the government's claim that its interest in fetal life is compelling before viability: "[A] State's interest in protecting fetal life is not grounded in the Constitution. Nor, consistent with our Establishment Clause, can it be a theological or sectarian interest."200

None of the justices who signed those opinions (Blackmun, Brennan, and Marshall) remain on the Court today. Still, it is revealing that three justices who signed the original Roe opinion, including its author, incorporated Justice Stevens's above-ground Establishment Clause argument into their later defenses and elaborations of $R o e$.

196 See Thornburgh, 476 U.S. at 779 (Stevens, J., concurring).

197 See id. at 772, 778-79 (Stevens, J., concurring); Webster v. Reprod. Health Servs., 492 U.S. 490, 560-72 (1989) (Stevens, J., concurring in part and dissenting in part); Planned Parenthood of Southeastern Pennsylvania v. Casey, 505 U.S. 833, 914-17 (1992) (Stevens, J., concurring in part and dissenting in part).

198 Webster, 492 U.S. at 552-53 (Blackmun, J., concurring in part and dissenting in part) (quoting Thornburgh, 476 U.S. at 778-79 (Stevens, J., concurring).

199 Id.

200 Casey, 505 U.S. at 932 (Blackmun, J., concurring in part, concurring in the judgment in part, and dissenting in part) (citing Thornburgh, 476 U.S. at 778 (Stevens, J., concurring)). 


\section{Planned Parenthood of Southeastern Pennsylvania v. Casey}

This Section discusses Casey, the Supreme Court's landmark 1992 abortion decision. ${ }^{201}$ Despite major revisions to Roe's understanding of abortion rights, the Court left Roe's UEC fundamentally intact, and it also added a new, distinct UEC argument. The opening section of the plurality opinion strongly suggested that the goal of prohibiting abortion is more about entrenching traditional sexual mores and gender roles than about protecting fetal life. By re-characterizing the interests of abortion opponents in this way, Casey dismissed those interests on the grounds that they involve ultimate concerns that belong to the domains of religion and the conscience of the individual, not politics.

\section{The "Essential Holding of Roe"}

In Casey, the justices split into several groups: two justices for reaffirming $R o e$ in unmodified form, ${ }^{202}$ four for overruling it, ${ }^{203}$ and three (O'Connor, Kennedy and Souter) signing onto a middle-of-the-road plurality opinion, ${ }^{204}$ which is now the authoritative legal text defining the scope of the constitutional right to abortion. The plurality justices defended what they vaguely referred to as the "essential holding of Roe."205

This so-called "essential holding of Roe" departs from Roe in some very important ways. Although Roe acknowledged the state's legitimate interest in potential life, it did not allow the state to advance that interest until viability. ${ }^{206}$ Casey, by contrast, emphasized that the state's interest is legitimate throughout pregnancy and allowed the state to advance that interest (up to a point) before fetal viability. ${ }^{207}$

This change, however, does not undermine Roe's UEC. The Casey plurality never questioned, reconsidered, or offered a rationale for Roe's refusal to answer when human life begins. It adopted the potential-life description of the government's interest without comment, ${ }^{208}$ which, as previous Sections of the Article have shown, is an important

201 See Casey, 505 U.S. at 833.

$202 \mathrm{Id}$. at 912-13 (Stevens, J., concurring in part and dissenting in part); id. at 92324 (Blackmun, J., concurring in part and dissenting in part).

203 Id. at 944 (Rehnquist, C.J., concurring in the judgment in part and dissenting in part); id. at 983, 999 (Scalia, J., concurring in the judgment in part and dissenting in part).

204 Id. at 846 (plurality opinion).

$205 I d$

206 See Roe v. Wade, 410 U.S. 113, 163 (1973).

207 Casey, 505 U.S. at 846, 876.

208 Id. at $870-71$. 
accompaniment of the Roe UEC, which refuses to say when actual life begins. ${ }^{209}$

Although Casey did strengthen the potential-life interest by allowing the government to regulate abortion before viability, the plurality joined Roe in saying that the interest is not compelling (only "legitimate") before viability. ${ }^{210}$ As a result, states are only allowed to regulate before viability in non-intrusive ways: they may not create an "undue burden" until after viability. ${ }^{211}$ Thus, Casey left the central result of Roe's UEC-the refusal to recognize a compelling interest in actual fetal life or pre-viable potential life - undisturbed and unexamined. ${ }^{212}$

\section{Casey's Additions to the Underground Establishment Clause}

Although the Casey plurality left the Roe UEC intact, it also expanded upon and modified the UEC in several ways. These expansions are the subject of this sub-section.

The first modification that Casey made to the UEC relates to the structure of Due Process doctrine. As I discussed previously in Section II.A, substantive due process analysis proceeds in two steps. The first question is whether a fundamental right is at stake; if so, the second is whether the government has a compelling interest that justifies violating the right. ${ }^{213}$ Roe used non-UEC arguments to establish that abortion is a constitutionally protected liberty, ${ }^{214}$ and it only resorted to the UEC to refute the government's claim that it had a compelling interest in protecting fetal life. ${ }^{215}$

By contrast, the portion of the Casey opinion authored by Justice Kennedy ${ }^{216}$ frequently blurred these two analytical steps and treated them as one. He did so by framing most of the ethical dynamics of the abortion decision - the reasons why abortion is a fundamental right, as well as the reasons why abortion might be immoral-as quasi-religious, ultimate concerns about the meaning of human life.

209 See supra Part II.A.6.

210 Casey, 505 U.S. at $870,879$.

$211 \mathrm{Id}$. at 876 .

212 This refusal to re-evaluate the core claims of $R o e$ is unsurprising in light of Casey's overall approach to the case: stare decisis, respect for precedent. See id. at 853-55 (arguing that stare decisis favors reaffirming Roe).

213 See supra Part II.A.1.

214 The Court primarily relied on recent Due-Process precedent and the "detriment" that unwanted pregnancies impose upon women. Roe v. Wade, 410 U.S. 113, 152-53 (1973).

215 See supra Part II.A.

216 For a discussion of who authored what in the Casey joint opinion, see JEFFREY Toobin, THE NINE: INSIDE THE SECRET WORLD of THE SUPREME CoURT 54 (2007). 
In the course of explaining why abortion is a constitutional liberty, Kennedy repeatedly alluded to the deep philosophical and spiritual roots of the controversies surrounding abortion. He indicated that the key question in the case (the "underlying constitutional issue") is "whether the State can resolve these philosophic questions in such a definitive way that a woman lacks all choice in the matter." ${ }^{117}$ In a well-known passage, Kennedy proclaimed: "At the heart of liberty is the right to define one's own concept of existence, of meaning, of the universe, and of the mystery of human life." 18 He further argued that people of "good conscience" disagree about "the profound moral and spiritual implications of terminating a pregnancy, even in its earliest stage." 219

Kennedy even implicitly identified himself with those who, for spiritual and moral reasons, oppose abortion: "Some of us as individuals find abortion offensive to our most basic principles of morality, but that cannot control our decision. Our obligation is to define the liberty of all, not to mandate our own moral code."220

Kennedy's sympathy with the moral opponents of abortion was unsurprising at the time, given that he is a practicing Catholic who had once called Roe the "Dred Scott of our time," and who just a few years before Casey seemed prepared to overturn Roe. ${ }^{221}$ In fact, after hearing oral argument in Casey, Kennedy initially indicated that he was prepared to join the four anti-abortion justices to create a majority against Roe. $^{222}$

What is surprising, though, is the way that he framed opposition to abortion (including his own) as a moral and spiritual concern that cannot legitimately be "mandate[d]" by the government. ${ }^{223}$ The vocabulary he used to describe the nature of the abortion controversy-as involving "basic principles of morality," "profound moral and spiritual implications," our "concept of existence, of meaning, of the universe," and "philosophic[al] questions" that government may not legitimately

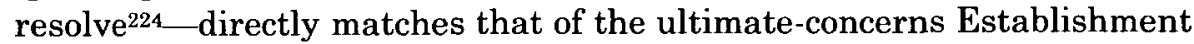
Clause objection to restrictive abortion laws. ${ }^{225}$ Like Justice Blackmun did in Roe, Justice Kennedy used ultimate concerns-themes as a way of mitigating the force of the State's interest in regulating abortion; but

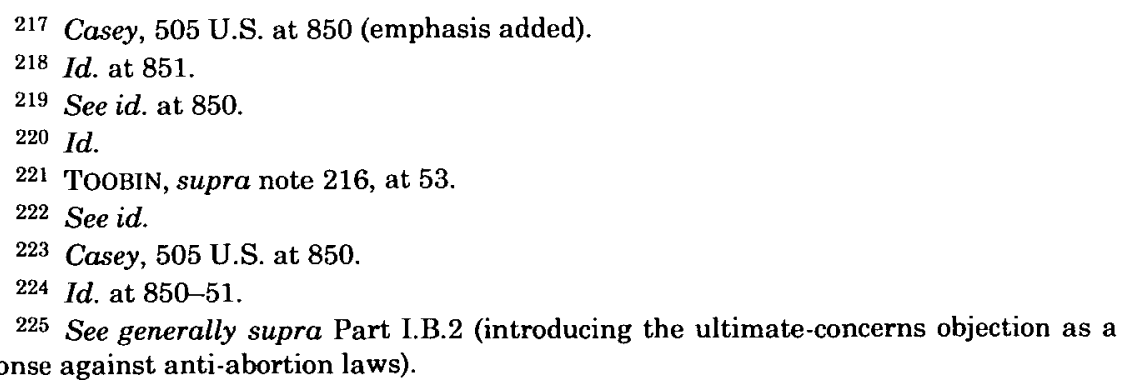


unlike Roe, Kennedy also (and primarily) employed ultimate concernsthemes as a way of showing why women have a fundamental liberty to seek an abortion in the first place.

Kennedy's argument expands the Roe UEC in another respect, as well. The Roe UEC targeted the government's interest in protecting fetal life, holding that it must not seek to definitively answer the question of when life begins. ${ }^{226}$ By contrast, the bulk of Kennedy's discussion of the "profound moral and spiritual" issues involved in abortion is not about the fetus, but about sexual morality and gender roles. ${ }^{227}$ For example, he analogized restrictive abortion laws to anti-contraception laws, suggesting that objections to both are "based on such reverence for the wonder of creation that any pregnancy ought to be welcomed and carried to full term." 228 Similarly, he indicated that when a government enforces anti-abortion laws, it insists "upon its own vision of the woman's role," which is inappropriate in light of how "intimate and personal" pregnancy and questions of gender role are for women. ${ }^{229}$

Thus, Casey left the Roe UEC intact and added new dimensions to it. Roe used the UEC to emphasize the importance of agnosticism about when life begins, which enabled the Court to reject the government's interest in protecting fetal life. Casey did not question, or even comment upon, this crucial component of the Roe UEC. Instead, the Casey plurality fashioned an additional UEC-type reason to reject abortion laws: such laws implicate ultimate moral and spiritual questions regarding gender roles and sexuality, which the government must not interfere with in our constitutional system.

\section{E. A Retreat: The Partial Birth Abortion Cases}

After Casey, the Court did not have to revisit the UEC until it decided two partial-birth abortion cases in 2000 and 2007. Confronted with and deeply disturbed by the phenomenon of partial-birth abortion, Kennedy substantially backtracked from the UEC that he had helped

226 See supra Parts II.A.4-5.

227 This is not to say that his argument has nothing to do with the fetal-life dimension of the abortion issue. He refers to it at one point in his summary of the moral complexity of abortion:

Abortion is a unique act. It is an act fraught with consequences for others: for the woman who must live with the implications of her decision; for the persons who perform and assist in the procedure; for the spouse, family, and society which must confront the knowledge that these procedures exist, procedures some deem nothing short of an act of violence against innocent human life; and, depending on one's belief, for the life or potential life that is aborted.

See Casey, 505 U.S. at 852.

228 Id. at 853.

229 Id. at 852 . 
develop in Casey, and even used language that, if taken to its logical conclusion, would lead to a rejection of the Roe-Casey UEC. This Section discusses the partial-birth abortion cases and explains how Kennedy's shifting views threaten the UEC.

\section{Background}

As the previous Section discussed, Kennedy was never entirely comfortable with Roe. ${ }^{230}$ Despite his misgivings, he ultimately found the decision palatable enough to join the Casey plurality and uphold Roe. For the traditional abortion procedures at issue in Roe and Casey, the fetus is located inside the womb and is generally invisible to the outside world. The invisibility of the fetus within the womb makes it easier to speak about the morality of abortion in abstract terms, as Kennedy did in Casey: "At the heart of liberty is the right to define one's own concept of existence, of meaning, of the universe, and of the mystery of human life." $" 31$

The partial-birth-abortion issue shattered the abstraction that helped make abortion rights acceptable to Kennedy. By the year 2000, when Stenberg $v$. Carhart came before the Supreme Court, approximately thirty states had banned the dilation-and-extraction (D\&X) abortion method. ${ }^{232}$ Unlike traditional abortion techniques, D\&X involves delivering a live fetus into the birth canal, leaving only the head undelivered. The abortionist then punctures the fetus's head and vacuums out its contents before finishing the delivery of the dead fetus. ${ }^{233}$

Whether this gruesome technique is morally different from traditional abortion is a controversial question in both pro-life and prochoice circles. ${ }^{234}$ Whatever the true answer to that question, the

\footnotetext{
230 See supra Part II.D.2.

231 See Casey, 505 U.S. at 851.

232 See Stenberg v. Carhart, 530 U.S. 914, 978-79 (2000) (Kennedy, J., dissenting).

233 Professor Cynthia Gorvey summarizes the procedure in the following way: [T] he abortionist uses forceps to pull a living baby feet-first through the birth canal until the baby's body is exposed, leaving only the head just within the uterus. The abortionist then forces surgical scissors into the base of the baby's skull creating an incision through which he inserts a suction tube to evacuate the brain tissue from the baby's skull. The evacuation of this tissue causes the skull to collapse, allowing the baby's head to be pulled from the birth canal.
}

Cynthia Gorney, Gambling with Abortion: Why Both Sides Think They Have Everything to Lose, HARPER'S, Nov. 2004, at 33, 34.

234 Many pro-choice citizens join pro-lifers to condemn partial birth abortion because it is too "close to infanticide." See, e.g., Barbara Vobejda \& David Brown, Harsh Details Shift Tenor of Abortion Fight: Both Sides Bend Facts On Late-Term Procedure, WASH. PosT, Sept. 17, 1996, at A1, A8 (quoting pro-choice Senator Patrick Moynihan). On the other hand, many on the pro-life side say that partial-birth abortion is no more terrible 
procedure certainly looks different: we can see a part of the fetus, in our world and outside of the world of the womb, at the time that its life is ended. ${ }^{235}$ When the fetus's life is being terminated outside of the seemingly foreign space of the womb, the question of fetal life becomes more dramatic, more urgent, and less abstract. If traditional abortion does not already look like infanticide, partial-birth abortion certainly does.

This does not mean, as a philosophical matter, that it actually is infanticide: I am speaking only of aesthetics here. Nonetheless, aesthetics often influence our ethical judgments, and the distinction between traditional and partial-birth abortion, whether purely aesthetic or morally relevant, is a vastly important one for Justice Kennedy.

\section{Stenberg $v$. Carhart}

When the Court struck down Nebraska's partial birth abortion ban in Stenberg, Justice Kennedy vigorously dissented. There was no trace of his lofty account of liberty in Casey, or his previous characterization of the abortion debate as centering on controversial issues about gender roles and sexual morality. Furthermore, he made the important rhetorical choice to speak of the fetus as a human life rather than the preferred UEC term: potential life. ${ }^{236}$

He repeatedly referred to the fetus as "unborn" "life" and as "human life."237 Whereas in Casey he spoke of how the Court must not "mandate [its] own moral code," and the legislature must not resolve "philosophic[al] questions" reserved to individual conscience, ${ }^{238}$ here he approved the "moral judgment" of Nebraska that "all life, including the life of the unborn, is to be respected." 239

He declared that legislatures must be allowed to "promote the life of the unborn and to ensure respect for all human life and its potential." 240 He described the D\&X procedure as one that "many decent and civilized people find so abhorrent" as to be one of the "most serious of crimes

than traditional abortion: both procedures kill the fetus; the only difference is the fetus's location at the time it is killed. See, e.g., Richard Stith, Location and Life: How Stenberg v. Carhart Undercut Roe v. Wade, 9 WM. \& MARY J. WOMEN \& L. 255, 267-68 (2003).

235 Stith, supra note 234, at 267.

236 See generally Helen M. Alvaré, Gonzales v. Carhart: Bringing Abortion Law Back into the Family Law Fold, 69 MONT. L. REV. 409, 409-10 (2008) ("[T]he Court's preGonzales abortion opinions were distinctly uncomfortable with language explicitly including fetal life within the category of human life. The opinions lack both internal consistency and consistency with each other in their use of language about fetuses.").

237 See Stenberg, 530 U.S. at 957 (Kennedy, J., dissenting).

238 Planned Parenthood of Southeastern Pennsylvania v. Casey, 505 U.S. 833, 850

(1992) (plurality opinion); see also supra Part II.D.2.

239 Stenberg, 530 U.S. at 964 (Kennedy, J., dissenting).

240 See id. at 957 (citing Casey, 505 U.S. at 871 (plurality opinion)). 
against human life."241 Furthermore, he chastised the Court for viewing D\&X "from the perspective of the abortionist, rather than from the perspective of a society shocked when confronted with a new method of ending human life." 242

\section{Gonzales v. Carhart}

Seven years later, the Court heard Gonzales $v$. Carhart, which dealt with the 2003 federal partial-birth-abortion ban. ${ }^{243}$ By then, Justice Alito had taken over Justice O'Connor's seat, and the five-justice Stenberg majority for striking down Nebraska's partial-birth-abortion ban yielded to the five-justice Gonzales majority for upholding the federal ban. Justice Kennedy wrote the majority opinion. Even though he had dissented in Stenberg, his Gonzales opinion claimed to respect and distinguish, not overrule, Stenberg. ${ }^{244}$

Whether Kennedy's distinctions between the Nebraska D\&X ban in Stenberg and the federal ban in Gonzales make sense is hotly debated, ${ }^{245}$ and it is not crucial for my point here. What is crucial is that the antiUEC rhetoric of his Stenberg dissent did make it into his Gonzales opinion. He approvingly recited the congressional findings that accompanied the legislation that the procedure will "coarsen society" to "all vulnerable and innocent human life." 246 In a particularly controversial passage, ${ }^{247}$ he dramatically humanized the fetus, even to the point of calling it an "infant life" and a "child":

Respect for human life finds an ultimate expression in the bond of love the mother has for her child. ... [S]ome women come to regret their choice to abort the infant life they once created and sustained. . . . [S] he allowed a doctor to pierce the skull and vacuum the fast-

241 Id. at 979.

242 Id. at 957.

243 Gonzales v. Carhart, 550 U.S. 124, 132 (2007).

244 See id. at 154 (citing Almendarez-Torres v. United States, 523 U.S. 224, 238 (1998)).

245 Compare Martha C. Nussbaum, The Supreme Court, 2006 Term - Foreword: Constitutions and Capabilities: "Perception" Against Lofty Formalism, 121 HARV. L. REV. 4, 84 (2007) (criticizing the Court's "bizarrely narrow" reading of Stenberg), with Christopher Mirakian, Comment, Gonzales v. Carhart: A New Paradigm for Abortion Legislation, 77 UMKC L. REV. 197, 208-09 (2008) (defending Gonzales's distinctions).

246 Gonzales, 550 U.S. at 157 (quoting 18 U.S.C. $\S 1531$, Congressional Findings (14)(N) (2000 ed., Supp. V)).

247 Compare Reva B. Siegel, The Right's Reasons: Constitutional Conflict and the Spread of Woman-Protective Antiabortion Argument, 57 DukE L.J. 1641, 1690-91 (2008) (criticizing Kennedy's language for reflecting gender-based stereotypes and undermining Roe and Casey), with Alvaré, supra note 236, at 410-11 (praising Gonzales for recognizing the emerging parental bond between pregnant mother and fetus, thereby making abortion law more like family law). 
developing brain of her unborn child, a child assuming the human form. ${ }^{248}$

Finally, Gonzales referenced and reinvented the crucial UEC passages from Kennedy's portion of the Casey plurality opinion. As I previously explained, Casey elaborately described the "anxieties," "pain," and "constraints" of pregnancy, and the deep "spiritual" implications of the decision of whether or not to procure an abortion, in order to show why the woman, and not the government, should make that choice based on her own moral view about the fetus and her gender role. ${ }^{249}$

On two occasions, Gonzales cited and summarized this section of Casey as standing for the proposition that "[w] hether to have an abortion requires a difficult and painful moral decision." 250 Whereas the Casey UEC saw the difficult and painful nature of the abortion decision (and pregnancy) as a reason to minimize the government's role, ${ }^{251}$ Gonzales used the same underlying fact for the opposite end: as a justification for governmental intervention. According to Kennedy, banning partial-birth abortion protects women from making a "painful" decision "fraught with emotional consequence" and thereby risking "[s]evere depression and loss of esteem." 252 The reason that Kennedy found it obvious and "unexceptional" that many women would regret procuring a (partialbirth) abortion is that, unlike in Casey, he now conceptualized the fetus as an "infant life," and the pregnant woman as a "mother" who would, naturally and predictably, lament the death of her child. ${ }^{253}$ Whether Kennedy intended to do so or not, his Gonzales opinion substantially eroded the UEC foundations of Roe and Casey by affirming the right of the State to recognize and protect the humanity of fetal life.

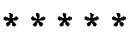

This Part has traced the origins of the UEC in Roe's rejection of the government interest in fetal life, its reaffirmation and expansion in Casey, and the powerful retreat from the UEC in Gonzales. The RoeCasey UEC depends on judicial agnosticism about when human life begins, whereas Kennedy's Stenberg dissent and Gonzales majority opinion unequivocally recognize the reality and value of fetal humanity. At present, the UEC hangs on by a thread.

248 Gonzales, 550 U.S. at $159-60$.

249 Planned Parenthood of Southeastern Pennsylvania v. Casey, 505 U.S. 833, 852 (1992).

250 Gonzales, 550 U.S. at 128-29, 159 (citing Casey, 505 U.S. at 852-53).

251 See supra Part II.D.2.

252 Gonzales, 550 U.S. at 159.

253 Id. 


\section{Evaluating THE EstablishmENT ClaAUSE OBJECTIONS TO ABORTION RESTRICTIONS}

Parts I and II documented the Establishment Clause arguments against abortion laws advanced by Justice Stevens, a number of commentators, and, in the veiled form of the UEC, the Court. Up to this point, the Article has been descriptive. This Part moves from the descriptive to the prescriptive by rebutting the political-divisiveness, ultimate-concerns, and faith-versus-reason arguments. I conclude that the Court should bring the UEC into plain view, reject it, and revisit the foundations of the constitutional right to abortion.

\section{A. The Paradox of the Political-Divisiveness Argument}

Although political divisiveness is the most common type of Establishment Clause objection to abortion restrictions, it is the least convincing. The initial attractiveness of the political-divisiveness argument lies in the strength of its factual premise: polling data and casual observation unequivocally reveal that abortion divides Americans along religious lines. ${ }^{254}$ There are exceptions to these demographic patterns: some religious people and groups are pro-choice, ${ }^{255}$ and some atheists pro-life. ${ }^{256}$ Nonetheless, the overall tendency is clear.

However, the argument fails because it attaches undeserved political and constitutional significance to these religion-related differences of opinion. The appeal to political divisiveness by courts to identify Establishment Clause violations has been persuasively criticized on numerous grounds, including that: (1) far from being a problem that demands intervention, disagreements are an "unavoidable part of the political life of a diverse and free people" and a sign that America is "functioning well";257 (2) religion-related divisions and discourse are "not necessarily more sectarian" or more troubling than ordinary secular divisions; ${ }^{258}$ (3) invalidating legislation on political-divisiveness grounds

254 A recent Pew survey found that in April 2009, 52\% of Protestants, 42\% of Catholics, and only $20 \%$ of unaffiliated persons said that abortion should be illegal. Among white Protestants, 70\% of white Evangelicals said abortion should be illegal, whereas only $34 \%$ of white mainline Protestants said so. PEW RESEARCH CENTER FOR THE PEOPLE \& THE PRESS, AMERICANS NOW DIVIDED OVER BOTH Issues: PUBliC TAKES CONSERVATIVE TURN ON GUN CONTROL, ABORTION 6 (Apr. 30, 2009), http://people-press.org/reports/pdf/513.pdf.

255 See, e.g., Catholics for Choice, CATHOLICSFORCHOICE.ORG, http://catholicsfor choice.org/about/default.asp (last visited Aug. 26, 2010).

256 See, e.g., James Matthew Wallace, Atheist and Agnostic Pro-Life League Homepage, GODLESSPROLIFERS.ORG (Jan. 1, 2007) http://www.godlessprolifers.org/home. html.

257 Garnett, supra note 64, at 1670 .

258 Michael J. Perry, Under God? Religious Faith and Liberal Democracy 4041 (2003). 
"chills the exercise" of political speech and participation by religious citizens; ${ }^{259}$ and (4) judicial intervention to alleviate political divisiveness often ends up stoking the flames of division because "deciding a dispute on the basis of some abstract legal principle rather than on the give-andtake of legislative compromise" tends to "increas[e] the bitterness" of the losing party. ${ }^{260}$

The fourth objection is particularly telling in the context of abortion. Many commentators have observed that "[l]egislative battles over the issue of legalized abortion seem to have become more bitter and divisive since the Supreme Court attempted to preempt the issue in Roe $v$. Wade." 261 As Mary Ann Glendon has convincingly shown, abortion never became as divisive in Western Europe as it is in America, in large part because the issue was handled primarily through public debate and legislative compromise rather than judicially crafted constitutional law. ${ }^{262}$ The contemporary state of affairs in America is frustrating not only to pro-life citizens, who feel impotent to effect change through ordinary political means, ${ }^{263}$ but also to pro-choice individuals who are "worried about Roe's demonstrated propensity to create backlash against the Democratic Party and progressivism more generally."264 Thus, judicial invalidation of restrictive abortion laws on political-divisiveness grounds presents a paradox: constitutional intervention has increased, not decreased, the religion-related political division surrounding the issue.

Finally, political divisiveness no longer plays a major role in judicial interpretation of the Establishment Clause. For a brief period during the 1970 s, the Court deemed "political division along religious lines" to be "one of the principal evils against which the First Amendment was intended to protect." 265 It is probably no coincidence that only two years after authoring that opinion, the Court in Roe emphasized and revealed its anxiety about the "vigorous opposing views" involved in the "abortion

259 Edward McGlynn Gaffney, Jr,, Political Divisiveness Along Religious Lines: The Entanglement of the Court in Sloppy History and Bad Public Policy, 24 ST. LouIS U. L.J. 205, 209 (1980).

260 Philip E. Johnson, Concepts and Compromise in First Amendment Religious Doctrine, 72 CALIF. L. REV. 817, 830 (1984).

261 E.g., id.

262 See Mary ann Glendon, Abortion and Divorce in Western LaW 46-47 (1987).

263 Johnson, supra note 264 , at 830 .

264 Robin West, From Choice to Reproductive Justice: De-Constitutionalizing Abortion Rights, 118 YALE L.J. 1394, 1397 (2009); see generally GERALD N. ROSENBERG, The Hollow Hope: CAN CoURTS BRING ABout Soclal CHANGe? (2d ed. 2008) (advancing a general argument that court-driven social change in favor of progressive social policy is ultimately ineffective).

265 Lemon v. Kurtzman, 403 U.S. 602, 622 (1971) (citing Freund, supra note 22). 
controversy."266 Yet as I explained in Part I, the law has changed on this point: a majority of the Supreme Court has decisively rejected the relevance of political divisiveness to Establishment Clause inquiry, and the Court has unanimously agreed that religion-related political divisiveness, by itself, is not enough to prove an Establishment Clause violation. ${ }^{267}$ These developments help to refocus the First Amendment on "legislative outcomes rather than political inputs, so that a statute's constitutionality is not impugned by the mere fact that some people supported it for religious reasons." 268

\section{B. Fetal Personhood and Human Dignity: An "Ultimate Concern" with Diverse Ideological Roots}

The ultimate-concerns objection to restricting abortion laws is stronger than the political-divisiveness argument, but it, too, is inadequate. Its central flaw is that, although abortion poses ultimate questions about why we value human life, liberty, and personhood, a pro-life answer to those questions can derive from many different ethical and religious (and non-religious) worldviews. When lower courts utilize an ultimate-concerns approach to defining religion, they consider three different factors: (1) do the beliefs at issue try to answer ultimate questions; (2) do those beliefs amount to a comprehensive belief system; and (3) does the system of belief accompany external forms of religion, such as ceremonies, hierarchy, and holidays?269

To begin with the obvious, the ultimate-concerns argument about abortion flunks the third factor of the test. No specific religious hierarchy, ceremonies, holidays, or other external "accoutrements" of religion are directly associated with pregnancy, abortion, or restrictive abortion laws. ${ }^{270}$ Pregnancy and abortion do, of course, have deep ethical significance to many religions, but that is different from saying that pregnancy or abortion are an exclusive part of the hierarchy, ritual life, or other external features of a narrow range of religious groups. The fact that abortion fails the third factor is not necessarily fatal to the ultimate-concerns argument, because it is only one factor among three. Nonetheless, it is important to keep in mind as we examine the other factors.

266 Roe v. Wade, 410 U.S. 113, 116 (1973); see also supra Part II.A.4.

267 See supra notes 71-73 and accompanying text.

268 Andrew Koppelman, Secular Purpose, 88 VA. L. REV. 87, 89 (2002).

269 See generally supra Part I.B.2 (discussing the ultimate-concerns definition of religion).

270 Cf. United States v. Meyers, 906 F. Supp. 1494, 1502-03 (D. Wyo. 1995) (providing an extensive list of the external features of religion), aff'd, 95 F.3d 1475, 148284 (10th Cir. 1996) (adopting the district court's method for defining religion). 
Most of the commentators who openly advance ultimate-concerns objections to abortion restrictions, and the Supreme Court justices who have done so under the guise of Due Process, strongly rely on the first factor (fundamental concerns) and, to a lesser extent, the second (comprehensiveness). Roe spoke of the "deep and seemingly absolute convictions" people hold about abortion, and traced these convictions to people's comprehensive belief systems: "One's philosophy, one's experiences, . . . one's religious training, one's attitudes toward life and family and their values," and so on. ${ }^{271}$ Casey likewise spoke of the "profound moral and spiritual implications of terminating a pregnancy," and connected the competing views about abortion to "our most basic principles of morality."272 Roe, Casey, and commentators are correct that for any particular individual, his or her views about abortion are likely to be connected with his or her comprehensive belief systems about morality and religion (or irreligion).

However, the belief that fetuses should be protected as persons is not limited to any single comprehensive belief system, or even a narrow subset of related belief systems. That belief can be understood and accepted within the framework of Roman Catholicism ${ }^{273}$ and various Protestant faiths, ${ }^{274}$ but also within Judaism, ${ }^{275}$ Islam, ${ }^{276}$ libertarianism, ${ }^{277}$ feminism, ${ }^{278}$ and even, as I will demonstrate in detail later on, a quintessentially secular, post-Enlightenment philosophical approach that elevates scientific reasoning and logic above

271 Roe, 410 U.S. at 116 (1973); see also supra Part II.A.4.

272 Planned Parenthood of Southeastern Pennsylvania v. Casey, 505 U.S. 833, 850 (1992) (plurality opinion); see also supra Part II.D.2.

273 See, e.g., Congregation for the Doctrine of the Faith, Instruction on Respect for Human Life in its Origin and on the Dignity of Procreation: Replies to Certain Questions of the Day, VATICAN.VA/PHOME_EN.HTM (Feb. 22, 1987), http://www.vatican.va/roman_curia/ congregations/cfaith/documents/rc_con_cfaith_doc_19870222_respect-for-human-life_en. html.

274 See, e.g., Thinking Theologically about ABorTion (Paul T. Stallsworth ed., 2000) (collection of presentations by pastors from an ecumenical conference about abortion).

275 See, e.g., David Novak, Covenantal Rights: A Study IN Jewish Political THEORY 129 (2000).

276 See, e.g., ABUL FADL MOHSIN EBRAHIM, BIOMEDICAL ISSUES: ISLAMIC Perspective 135-37 (rev. ed. 1993).

277 See, e.g., Richard A. Epstein, Substantive Due Process by Any Other Name: The Abortion Cases, 1973 SuP. CT. REV. 159, 170-71 (1973) (arguing that abortion violates John Stuart Mill's harm principle and therefore can be legally prohibited by a libertarian government); see also Libertarians for Life, The Libertarian Case Against Abortion, L4L, http://www.14l.org/ (last visited Sept. 10, 2010).

278 See, e.g., Paulette Joyer, Pro-Life and Feminism: No Opposition, in Pro-LIFE FEMINISM: DIFFERENT VOICES 1 (Gail Grenier Sweet ed., 1985); see generally Feminists for Life of America, FEMINISTSFORLIFE.ORG, http://www.feministsforlife.org/who/joinus.htm (last visited Sept. 19, 2010). 
metaphysics. ${ }^{279} \mathrm{My}$ point is not that the premises of any or all of these systems lead ineluctably to pro-life conclusions; that is clearly not the case, as there are many sensible pro-choice adherents to these various worldviews. Rather, the point is that pro-life views (like pro-choice ones) can find plausible expression within a wide variety of comprehensive systems and should not be seen as the necessary or exclusive property of any particular system.

The fact that belief in fetal humanity can cut across the boundaries of many different comprehensive systems severely undermines the ultimate-concerns objection to abortion laws, because the first factorwhether the belief system addresses fundamental questions-is generally not enough to invalidate a law. As the leading judicial opinion on the ultimate-concerns approach explained, "[c]ertain isolated answers to 'ultimate' questions . . . are not necessarily 'religious' answers, because they lack the element of comprehensiveness. . . . A religion is not generally confined to one question or one moral teaching." 280

This principle ought to be strictly maintained. Individual views about many central political goals, including how (and whether) to alleviate poverty, protect the environment, and safeguard human rights, frequently derive from our deepest convictions and beliefs about the nature and value of human life. Despite the fact that these issues implicate fundamental questions-and, for any given individual, are often answered on the basis of his or her comprehensive ethical-religious belief system-any particular governmental solution to these problems is likely to be consistent with many, though not all, comprehensive worldviews. For example, using the welfare state to fight poverty arguably fits well within Catholic, ${ }^{281}$ egalitarian, ${ }^{282}$ or utilitarian worldviews, ${ }^{283}$ and it probably contradicts other comprehensive ethical systems in which the first principles are self-reliance, freedom of action,

279 See infra Part III.C.

280 Malnak v. Yogi, 592 F.2d 197, 208-09 (3d Cir. 1979) (Adams, J., concurring in the judgment).

281 See United States Conference of Catholic Bishops, Welfare Policy: TANF Reauthorization, UsCCB.oRG (Feb. 24, 2006), http://www.usccb.org/sdwp/national/tanf206. shtml; see also CATHOlic CAMPAign for Human Development, U.S. CONFERENCE of Catholic Bishops, Preferentlal Option For and WiTH THE POOR (1996) (explaining society's duty to the poor according to catholic social teaching).

282 See, e.g., Elizabeth Anderson, How Should Egalitarians Cope with Market Risks?, 9 THEORETICAL INQUIRIES L. 239, 263 (2008) ("Egalitarians support distributive constraints that prevent the conversion of wealth inequality into an unjust social hierarchy, and ensure that everyone in society has enough to stand in relations of equality to others.").

283 See, e.g., Amartya Sen, Utilitarianism and Welfarism, 76 J. PHLl. 463, 468 (1979). 
or other libertarian ideals. ${ }^{284}$ Even though the question of welfare relates to fundamental questions and intersects with various comprehensive systems, it cannot be said to establish any one of those systems.

Therefore, because regulating abortion, like promoting the welfare state, is consistent with numerous comprehensive belief systems, the ultimate-concerns UEC fails. By remaining underground, the Court's abortion cases were able to frame the morality of abortion as a religious issue implicating ultimate concerns, while avoiding the need to back up its claim by proving that objections to abortion only make sense within a narrow range of comprehensive belief systems, at the exclusion of other systems.

\section{Faith Versus Reason}

\section{Introduction: Evaluating the Objection Based on Its Own} Methodological Premises

Although the Court's UEC consists primarily of politicaldivisiveness and ultimate-concerns themes, and only marginal faithversus-reason themes, the latter is the most formidable of the various arguments. To briefly recap, the faith-versus-reason argument allows the government (and potentially courts) to answer the question of when a fetus becomes a human being. The important caveat is that the government's answer must be a secular one. Secular answers are those that can be rationally justified by using only secular methods of reasoning. According to the faith-versus-reason argument, secular reasoning supplies no basis for believing that fetuses are persons until approximately viability; therefore substantial protections for pre-viable fetuses have no secular purpose. ${ }^{285}$

Numerous aspects of the faith-versus-reason argument are debatable; this sub-section brackets several areas of controversy, not because they are unimportant, but in order to focus the discussion. First, the argument necessarily relies on the idea that even when the government is trying to further an indisputably secular purpose (here, preventing homicide against human persons), it may not use religious knowledge concerning facts about our world that are relevant to furthering that secular purpose. Applying this method to the case of abortion, if the source of the knowledge/belief that a fetus is a human person comes from religion, then that (religious) belief cannot justify restricting abortion. Excluding religious knowledge claims that are used in the service of secular purposes (here, the purpose of preventing

284 See, e.g., RoBert NozICK, ANARCHY, STATE, AND UTOPIA 152 (1974) (analogizing redistributive taxation to slavery).

285 See supra Part II.C.3. 
homicide) is debatable, among other reasons, because it forces religious persons to divide up the religious and secular parts of their mental life as a condition for political participation. ${ }^{286}$

If we were to accept that religious knowledge may legitimately be used in politics to further secular purposes, the faith-versus-reason objection would be defeated. After all, there is no dispute about whether preventing the killing of human beings is a valid secular goal; the only question is whether killing fetuses qualifies as killing human beings, or, put differently, whether fetuses are human beings. If it does not violate the Establishment Clause to base political judgments on religious knowledge claims (here, the claim that a fetus is a human being), then the inquiry is at an end. In order to focus my criticism on a different aspect of the faith-versus-reason argument, I will assume arguendo that religious knowledge claims, even those that are relevant to furthering secular purposes, should be excluded from political deliberation.

Even once the faith-versus-reason argument overcomes that hurdle, the objector is still left with the task of distinguishing religious from secular reasoning. Some religious believers, and postmodern nonreligious thinkers, believe that this task is impossible. They contend that the Enlightenment's separation of faith and reason is a fiction, and that ethical and even scientific knowledge is ultimately based on faith commitments and non-rational worldviews. ${ }^{287}$

This objection, too, would defeat the faith-versus-reason argument by depriving it of any criterion for distinguishing "secular" modes of analysis from "religious" ones. Again, instead of resolving this complex objection, I will grant the elusive distinction between faith and reason,

286 See, e.g., Kent Greenawalt, Religiously Based Judgments and Discourse in Political Life, 22 ST. JoHN's J. LEGAL COMMENT. 445, 480-81 (2007).

Were citizens and officials permitted to rely on nonreligious intuitions but not to rely on religious convictions, that would constitute a form of implicit discrimination against religious perspectives. Moreover, any religious individual would have a hard time saying where his religious convictions left off and what his intuitions would tell him apart from these convictions.

Id. But see Robert Audi, The Place of Religious Argument in a Free and Democratic Society, 30 SAN DIEGo L. REV. 677, 701 (1993) ("If you are fully rational and I cannot convince you of my view by arguments framed in the [non-religious] concepts we share as rational beings, then even if mine is the majority view 1 should not coerce you.").

287 See, e.g., Thomas S. KuHN, THE STRUCtURe of SCIENTIFIC REVolutions 170 (3d ed. 1996) (arguing that scientific progress reflects "changes of paradigm" rather than objective progress toward truth).

What compels one to [science] . . is the belief in a metaphysical value, a value in itself of truth . . . . [W]e knowers today, we godless ones and antimetaphysicians, we too still take our fire from that great fire that was ignited by a thousand-year old belief, that belief of Christians, which was also Plato's belief, that God is truth, that truth is divine ... .

Friedrich NietzSCHE, ON THE GENEALOGY OF MORALITY 109-10 (Maudemarie Clark \& Alan J. Swensen trans., 1998). 
for the sake of argument, in order to evaluate the faith versus reason argument on the basis of its own core premises. According to Justice Stevens and other proponents of the faith-versus-reason argument, the distinction between religious and secular reasoning is this: religion relies on faith and intuition, whereas secular reasoning relies on "history," "logic," and "shared experiences." 288 I will address each of these three modes of secular reasoning to show how, individually and together, they provide a cogent secular case for fetal personhood.

It is not my goal here to prove that the fetus is a human person, or that fetal personhood is the only conclusion that can logically be deduced from logic, history, and experience. Instead, I aim to show that there is a debatable, secular case for fetal personhood. If I accomplish this limited goal, it is not enough to justify criminalizing or severely restricting abortion, but it is enough to prove that abortion laws have a secular purpose and do not violate the Establishment Clause. ${ }^{289}$ With this clarification in mind, I turn to the three major modes of secular reasoning identified by Justice Stevens: "history," "logic," and "shared experiences."

\section{History}

One mode of reasoning that faith-versus-reason advocates identify as secular is historical reasoning. ${ }^{290}$ This sub-section demonstrates that

288 Thornburgh v. Am. Coll. of Obstetricians \& Gynecologists, 476 U.S. 747, 779 (1986) (Stevens, J., concurring); see also discussion supra Part I.B.3.

289 Politics is pervasively debatable and debated, and many "secular" ideas compete against one another in the marketplace of ideas. Some of these secular ideas are right; others are wrong. Thus, an idea need not be proven beyond a reasonable doubt in order to count as secular. It only needs to have some plausible secular basis. See, e.g., Edwards v. Aguillard, 482 U.S. 578, 586 (1987) (observing that "the Court is normally deferential to a State's articulation of a secular purpose").

290 In some ways, it is odd to treat the historical longevity of a practice as a mark of its secularity; many outside of legal circles claim that precisely the opposite is true. According to the gripping secular and progressive narrative of the Enlightenment, human history is shrouded in darkness, religion, and superstition, which we are gradually moving beyond thanks to the interrelated pillars of science, tolerance, and secularism. The historical and traditional marks the unenlightened and non-secular, and the contemporary generally marks the rational. See, e.g., AUGUSTE COMTE, THE POSITIVE PHILOSOPHY OF AUGUSTE COMTE 25 (AMS Press, Inc. 1974) (1855) (dividing the historical development of humanity into three "progressive" stages, with one supplanting the other: "the [t]heological, or fictitious; the [m] etaphysical, or abstract; and the [s]cientific, or positive").

Nonetheless, courts generally value history for a variety of reasons that are not plausibly characterized as "religious." First, it is useful for constitutional interpretation: to the extent that the goal is to discover what the Constitution's framers meant (which, of course, is controversial), history helps us discover the original meaning of, or original intentions behind, the text. Second, a nation's history unites it. Even if the roots of a nation's historical practice were religious, respecting those longstanding traditions today might further the secular goal of unifying society around shared symbols. And finally, 
history supplies plausible (though not indisputable) arguments in favor of fetal personhood.

There are two ways that history might be used to create a secular case for fetal personhood: a direct way and an indirect way. The direct way is to show that for much of Anglo-American history, law and society frequently treated fetuses like human persons and condemned abortion. There is a strong case to be made for this view, but it is a hotly disputed claim, with a vast amount of scholarly commentary on both sides. ${ }^{291}$ In fact, most of Justice Blackmun's opinion in Roe was devoted to arguing his side of that issue. ${ }^{292}$ The dispute is too large to resolve in this Article. Nonetheless, the robustness of the debate tends to show that concern for fetal personhood (and the opposing position) has some historical (ergo secular) foundation.

Furthermore, history can assist the case for fetal personhood through a more indirect route. Many skeptics and religious persons contend (for different reasons, but their central claim is similar) that the core ideals of American political theory-rights, equality, dignity, personhood, and others - are metaphysical and/or religious concepts that cannot be justified by secular reasoning alone. ${ }^{293}$ Much of the secular case that the pro-life (and, interestingly, pro-choice) side puts forward depends crucially on these contested concepts.

This is where history offers decisive assistance. I do not need to prove that those concepts (equality, liberty, personhood, and dignity) can be supported by secular philosophical logic alone, because history places them at the heart of American political theory. Protecting the equality

every generation cannot reinvent the entirety of human knowledge. History is useful as a repository of human experience and of the mistakes and lessons of past ages. See, e.g., Oliver Wendell Holmes, The Path of the Law, in THE MIND AND FAITH OF JUS'TICE HoLMES 71, 83 (Max Lerner ed., 1943) (arguing that history is "the first step toward an enlightened skepticism, that is, towards a deliberate reconsideration of the worth of [existing laws]").

291 For an illustration of several of these views, see supra note 117.

292 See Roe v. Wade, 410 U.S. 113, 129-52 (1973).

293 See, e.g., 2 JEREMY BenthaM, Anarchical Fallacies, in ThE WORKS OF JEREMY BENTHAM 489, 501 (1843) ("Natural rights is simple nonsense: natural and imprescriptible rights, rhetorical nonsense,--nonsense upon stilts."); ROBERT P. KRAYNAK, CHRISTIAN FaITH AND MODERN DEMOCRACY: GOD AND POLITICS IN THE FALLEN WORLD 11 (2001) ("[T]he distinctive feature of modern liberal democracy is a notion of justice whose fundamental assumptions are the intrinsic worth and dignity of every human being and the preeminence of the human species in the natural universe. . . . [L]iberal democracy is unable to vindicate these lofty claims about human dignity . . . . Hence, . . . liberal democracy cannot stand on its own and needs support from the biblical claim that human beings are made in the image and likeness of God."); John T. Noonan, Jr., A Catholic Law School, 67 NOTRE DAME L. REV. 1037, 1042 (1992) (arguing that the legal concept of a "person. . . can be philosophically defended, but which historically developed under theological auspices, with human beings understood by analogy to the divine persons" of the Holy Trinity); Steven Pinker, The Stupidity of Dignity, THE NEW REPUBLIC (May 28, 2008, 12:00 AM), http://www.tnr.com/article/thestupidity-dignity. 
and rights of rational persons is one of the central animating ideas in America's political theory and in its founding documents, such as the Constitution and the Declaration of Independence. ${ }^{294}$ Those commitments have shaped how Americans understand their identity as a people.

Needless to say, there are grave contradictions in America's historical self-understanding as a nation of liberty and equality, ${ }^{295}$ including (among many other things) the institution of slavery and the protections bestowed upon that institution in the Constitution. ${ }^{296}$ Despite these stains and inconsistencies, America's historical and constitutional commitment to the equality of all persons is substantial enough to show that such notions are indisputably "secular" for Establishment Clause purposes. This conclusion does not directly refute the faith-versus-reason objection to abortion laws, but it does show that equality and personhood are valid secular concepts that abortion opponents may use as starting points for moral and political analysis. The next two sub-sections do precisely this, demonstrating how logic and experience can be plausibly used to include fetuses within the category of human persons who are entitled to rights and equal protection.

\section{Logic}

This sub-section discusses how secular logic can support the proposition that fetuses are human persons. Pro-life scholars have advanced elaborate logical arguments to show that fetuses are human beings. These arguments are part of the complex, ongoing debate in

294 See, e.g., U.S. CONST. amend. XIV, § 1 ("No State shall make or enforce any law which shall abridge the privileges or immunities of citizens of the United States; nor shall any State deprive any person of life, liberty, or property, without due process of law; nor deny to any person within its jurisdiction the equal protection of the laws."); THE DECLARATION OF INDEPENDENCE para. 2 (U.S. 1776) ("We hold these truths to be selfevident, that all men are created equal, that they are endowed by their Creator with certain unalienable Rights, that among these are Life, Liberty and the pursuit of Happiness.").

295 See H. MARK RoelofS, IDEOlOgY AND MYTH IN AMERICAN POlitics: A CRITIQUE OF A NATIONAL Political Mind 148 (1976) ("[T] he American people have no realistic intention of turning the dream [of egalitarianism] into reality. In pragmatic terms, Americans have only the most ambiguous commitment to egalitarianism at the operative level, either in specific terms of the race issue or on general principles. At the operative level, Americans are libertarians and are therefore not just tolerant but encouraging of inequalities of every kind.").

296 The most prominent traces of slavery in the Constitution are the Fugitive Slave Clause, U.S. CoNST. art. IV, § 2, cl. 3 ("No Person held to Service or Labour in one State, under the Laws thereof, escaping into another, shall, in Consequence of any Law or Regulation therein, be discharged from such Service or Labour . ..."), and the Three Fifths Clause, U.S. CoNST. art. I, $\S 2$, cl. 3 (designating those who are not "free Persons" as "three fifths of all other Persons" for purposes of apportioning votes among the states). 
philosophy circles about the morality of abortion. ${ }^{297}$ For the sake of brevity, this sub-section focuses on one part of the larger philosophical debate.

The argument I examine here reverses the usual battle lines in the abortion debate by embracing a scientifically accepted definition of when human life begins, linking "personhood" to the scientific definition of human "life," and accusing the pro-choice side of engaging in metaphysical speculation unhinged from science by defining "personhood" distinctly from scientific "life." 298 This contention is highly relevant for the Establishment Clause dimension of the abortion debate, because the tendency to privilege scientific reasoning over metaphysics is one of the central dynamics of Enlightenment secularism. ${ }^{299}$ If the case for fetal humanity can find a plausible home within the scientific, antimetaphysical tradition of the Enlightenment, then it has an airtight case for secularity, and the Establishment Clause objection to abortion laws decisively fails..$^{300}$

297 For two examples, see Patrick Lee \& Robert P. George, The Wrong of Abortion, in CONTEMPORARY DeBates IN APPLIED ETHICS 13, 13 (Andrew I. Cohen \& Christopher Heath Wellman eds., 2005) (arguing that human life is present beginning at conception, and that personhood, too, is present because all human life has a natural capacity for "development toward human maturity"); Don Marquis, Why Abortion is Immoral, $86 \mathrm{~J}$. PHIL. 183 (1989) (arguing that abortion wastes the value of the fetus's human future). These arguments are the subject of ongoing and extensive debate. See, e.g., Dean Stretton, Essential Properties and the Right to Life: A Response to Lee, 18 BIOETHICS 264, 264 (2004).

298 In a sense, pro-life anti-metaphysical arguments turn the Establishment Clause objection on its head. Insofar as non-scientific, metaphysical beliefs are "religious" beliefs and inappropriate for politics (as some of the liberal Establishment Clause arguments suggest), it is the pro-choice position that would come under scrutiny.

299 David Hume colorfully expressed the anti-metaphysical spirit of modernity in the following way:

If we take in our hand any volume; of divinity or school metaphysics, for instance; let us ask, Does it contain any abstract reasoning concerning quantity or number? No. Does it contain any experimental reasoning concerning matter of fact and existence? No. Commit it then to the flames: for it can contain nothing but sophistry and illusion.

DAVID Hume, ENQUiRIES ConCERning Human Understanding and Concerning THE Principles of Morals 165 (L.A. Selby-Bigge ed., 3d ed. 1975). See generally PhILIP WALsh, SKePticism, Modernity AND CRITICAL THeORY 4 (2005) ("Hume's skeptical empiricism is generally acknowledged as materialist and progressive, in tune with the overall thrust of Enlightenment values and of liberalism as a political and moral philosophy. It is hard-nosed, opposed to metaphysical system-building and directs attention to the empirical limits and constraints on knowledge." (emphasis added)).

300 This does not mean that the pro-life position is ultimately correct. There are good reasons to embrace metaphysical reasoning. See, e.g., YUVAL STEINITZ, IN DEFENSE OF METAPHYSICS 2 (Noah J. Efron trans., 1996). My point is merely that anti-metaphysical skepticism has good secular credentials, that the pro-life position regarding fetal life can be powerfully supported by this sort of method, and therefore that the pro-life view of fetal personhood can qualify as "secular." 
Justice White's opinion in Thornburgh $v$. American College of Obstetricians and Gynecologists contains the seeds of an antimetaphysical pro-life argument, and his dialogue with Justice Stevens illustrates what such an argument would look like. In a surprising sentence, White effectively agrees with one of Stevens's central premises by saying that the question of fetal humanity is a "metaphysical or theological question." 301 Yet rather than condemning abortion restrictions on that basis, he turns that fact against Roe, against Stevens, and in favor of fetal protection.

He begins with the scientific observation that a fetus of any age is a human being in the narrow sense that it is a "member of the species homo sapiens." 302 There is no serious disagreement on this point: it is a bare scientific fact that embryology textbooks confirm ${ }^{303}$ and abortionrights supporters concede. ${ }^{304}$ The real dispute is over whether these human organisms are human persons - that is, do they have the types of characteristics that we value in born human beings?

White goes on to say that any deviation from this scientific baseline-any attempt to define the origin of human personhood at a moment other than the scientific origin of life-is non-scientific and therefore is a metaphysical claim. He argues that metaphysical linedrawing in this area is doomed to fail because "there is no [nonarbitrary] line separating a fetus from a child or, indeed, an adult human being." 305 White's reasoning places the burden of proof on the prochoice side to provide a clear metaphysical definition of personhood that includes born humans but excludes (some or all) fetuses.

White does not systematically apply his anti-metaphysical framework to deconstruct the numerous pro-choice attempts to define human personhood, but many other pro-life scholars have energetically done so. ${ }^{306}$ Because Stevens is a leading proponent of the faith-versusreason argument, I will illustrate how these metaphysically-skeptical

301 Thornburgh v. Am. Coll. of Obstetricians and Gynecologists, 476 U.S. 747, 792 (1986) (White, J., dissenting).

${ }^{302} \mathrm{Id}$.

303 See, e.g., Ronan O'Rahilly \& Fabiola Muller, Human Embryology \& TERATOLOGY 8 (3d ed. 2001) ("Although life is a continuous process, fertilization . . . is a critical landmark because, under ordinary circumstances, a new, genetically distinct human organism is formed when the chromosomes of the male and female pronuclei blend in the oocyte.").

304 For instance, Mary Anne Warren's classic pro-choice essay acknowledges that embryos are, biologically speaking, human organisms. She goes on to argue that the personhood of the embryo does not follow from its biological classification as a human life, because embryos and young fetuses lack the properties that define personhood. Mary Anne Warren, On the Moral and Legal Status of Abortion, 57 MONIST 43, 55-56 (1973).

305 Thornburgh, 476 U.S. at 792 (White, J., dissenting).

306 See, e.g., Lee \& George, supra note 297, at 15-19. 
pro-life arguments work by analyzing Stevens's proposed criteria for human personhood.

Stevens asserts that it is "obvious" that the interest in protecting embryonic life "increases progressively and dramatically as the organism's capacity to feel pain, to experience pleasure, to survive, and to react to its surroundings increases day by day." 307 Based on these criteria, Stevens concludes that there is "a fundamental and wellrecognized difference between a fetus and a human being." 308

However, each of Stevens's proposed criteria for defining personhood is problematic: if accepted as a metaphysical truth and taken to its logical conclusion, each criterion would result in unacceptable conclusions. To begin with, consider Stevens's reference to the "capacity... to survive." 309 Although Stevens only mentions this criterion in passing, many pro-choice scholars who draw the personhood line at fetal viability heavily emphasize the moral significance of independence and survivability. ${ }^{310}$ Measuring personhood by viability, however, implies that our worth as humans is measured by our lack of dependency, our self-reliance, and our strength. Valuing human beings for those reasons, taken to its logical conclusion, culminates in a brutal Social Darwinist ethos in which the weak and non-viable, who are dependent and cannot survive on their own, are dehumanized and discarded. This inhumane result is unacceptable, particularly within the egalitarian and welfarist worldviews that many liberal, pro-choice persons generally embrace. In any event, it is difficult to imagine what moral or metaphysical significance the technical capacity to survive on one's own carries with it. Unless viability is being used as an approximate marker for some other morally significant development (such as the fetus's development of psychological consciousness, ${ }^{311}$ which I discuss further below), it does not identify a morally significant characteristic that justifies a firm metaphysical basis for defining personhood.

Similarly, Stevens's reference to the fetus's "capacity to feel pain" and "experience pleasure" cannot be decisive or even particularly

307 Thornburgh, 476 U.S. at 778 (Stevens, J., concurring).

308 Id. at 779 .

309 Id. at 778 .

310 See, e.g., Tribe, The Supreme Court, 1972 Term, supra note 8, at 27 (arguing that once a fetus can live on its own outside the womb, abortion unnecessarily kills a fetus that could just as easily be delivered and survive).

311 Viability and consciousness do not coincide precisely, but many commentators support drawing the line at viability on the grounds that it is a decent, if non-exact, approximation of when fetuses become conscious. See supra note 103 and accompanying text. 
important. ${ }^{312}$ Causing pain or depriving pleasure from another person is usually unjust and regrettable, but much less so than killing another person. ${ }^{313}$

If fetuses are human beings, then their inability to feel pain does not justify ending their lives any more than the physical insensitivity of adult lepers gives us license to end theirs. The basis for depriving fetuses of their lives must rely on some criterion other than capacity for pleasure and pain.

An alternative interpretation of Stevens's analysis is that he is not emphasizing pain and pleasure as decisive in and of themselves, but instead for what they tell us about whether the fetus is "sentient." 314 Identifying personhood with sentience or other forms of advanced psychological development is the leading approach in pro-choice philosophical thought. ${ }^{315}$ Yet this criterion, too, results in disturbing and dubious conclusions. When a person goes to sleep, or falls into a temporary coma, we do not say that she is no longer a person, despite her temporary lack of sentient awareness. ${ }^{316}$ Much less do we say that such a person is no longer morally equal to others, or that she has temporarily forfeited her right to life such that we may kill her without committing a grave injustice. Thus, a human organism need not have

312 Thornburgh, 476 U.S. at 778 (Stevens, J., concurring).

313 The strongest counter-argument to this point comes from the type of utilitarianism advanced by Jeremy Bentham, in which the only relevant criterion for valuing human beings (or other organisms) is their capacity for pleasure and pain. See JeREMy Bentham, AN INTRODUCTION TO THE PRINCIPLES OF MORALS AND LEGISLATION 310 n.1 (Hafner Publ'g Co. 1948) (1789) ("The day may come, when the rest of the animal creation may acquire those rights which never could have been withholden from them but by the hand of tyranny. . . What . . should trace the insuperable line? Is it the faculty of reason, or, perhaps, the faculty of discourse? . . [T] [Te question is not, Can they reason? nor, Can they talk? but, Can they suffer?"). However, instead of vindicating constitutional principles (as Stevens seeks to do), endorsing Bentham's form of utilitarianism would radically contradict the egalitarian and rights-protective orientation of American politics. It would entail distinguishing the value of different human beings based on the intensity of their sensory faculties and their level of happiness or depression. This is a result that few would accept.

314 Thornburgh, 476 U.S. at 779 (Stevens, J., concurring).

315 Pro-choice philosophers generally agree that consciousness or some other advanced psychological feature is crucial. They sometimes differ on which psychological attribute is most important. Compare MiCHAEL TOOLEY, ABORTION AND INFANTICIDE 41920 (1983) (emphasizing "the possession, either now or at some time in the past, of a sense of time, of a concept of a continuing subject of mental states, and of a capacity for thought episodes"), with JEFF MCMAHAN, THE ETHICS OF KiLling 260 (2002) (emphasizing the possession of "certain higher psychological capacities" including "autonomy").

316 E.g., Marquis, supra note 297, at 197. 
present conscious awareness in order to have rights or to count as a person. ${ }^{317}$

An additional reason to reject the advanced-psychologicaldevelopment criterion for personhood is that it would justify infanticide. If we define human personhood in terms of the functional capabilities of developed persons-self-consciousness, rationality, and so on-then we are almost certain to eliminate the humanity of born infants as well. Humans develop neither meaningful rationality nor a robust concept of self until well after birth, so the pro-choice functional definitions of personhood would justify "aborting" young infants. ${ }^{318}$ A small but growing minority of pro-choice academics are willing to accept this conclusion and to recognize infanticide as morally permissible under some circumstances, ${ }^{319}$ but most still unequivocally reject the killing of newborns. The refusal of mainstream pro-choice scholars to accept infanticide, although highly commendable, creates inconsistencies within the pro-choice metaphysical account of human personhood and gives powerful ammunition to those on the pro-life side who seek to deconstruct it.

The anti-metaphysical pro-life argument is not irrefutable, but it is formidable. It reverses the burden of proof and makes it appear as though the pro-choice side is the one engaged in the task of nonscientific, metaphysical, and arbitrary line-drawing. Thus, a major part of the pro-life case can plausibly situate itself within the antimetaphysical tradition of secular reasoning.

\section{Experience}

Proponents of the faith-versus-reason argument also identify "shared experiences" as another legitimate element of secular reasoning. The usefulness of looking to "shared experiences" for determining whether beliefs are religious or secular is ambiguous at best. For a majority of Americans, religion forms one part of their overall life experience, ${ }^{320}$ and this experience is often shared through communities

317 The counter to my argument is that the capacity for consciousness, not actual present consciousness, is the defining characteristic of personhood. But this counter plays directly into the pro-life philosophers' trap. Their argument is that the fetus is a person, because, even though it does not presently possess consciousness (like the sleeping person), it has a root "capacity" to develop consciousness if it is allowed to continue its life and growth. See, e.g., Lee \& George, supra note 297, at 15-18.

318 See, e.g., id at 18.

319 See, e.g., TOOLEY, supra note 315 at 421.

320 For instance, a February 2008 Pew survey found that $78.4 \%$ of Americans identified themselves as Christians, $4.7 \%$ identified with non-Christian religions, and only 1.6\% are atheists. PEW Forum on Religious \& PUB. LiFE, U.S. Religious Landscape SURVEY 5 (2008), available at http://religions.pewforum.org/pdf/report-religious-landscapestudy-full.pdf. 
of worship and through aspects of religious experience that are common to many different religions and cultures. ${ }^{321}$ Despite these problems with using "shared experiences" as a proxy for secularity, I will set aside the objection, arguendo, in order to focus on two core dimensions of human experience that faith-versus-reason proponents would accept as secular: sensory experience and relational experience.

Sensory experience, by itself, cannot directly say whether fetuses are persons. Personhood is not a thing that we see, smell, taste, or touch; it is a moral and philosophical concept. Still, sensation does provide important data that we use as part of our overall judgments about personhood. Traditionally, quickening (when the pregnant mother first feels the baby moving inside of her) marked the moment when "a child came into the family," resulting in "commitment" and "responsibility" for that child. ${ }^{322}$

During the past few decades, technology has enabled us to visualize the developing fetus while it remains in the womb; as a result, the traditional significance of quickening has been replaced with visual sensation. ${ }^{323}$ Both pro-choice and pro-life advocates appeal to visual imagery to draw inferences about fetal personhood. For instance, many pro-choice advocates appeal to visual imagery as a way to diminish fetal personhood by referring to unborn life (especially embryos or early fetuses) as a mere clump of cells or a "tiny little spot of blood."' 324 The pro-life movement contests these descriptions of the fetus through a variety of visually oriented methods. Pro-life literature and media is replete with clips from ultrasound videos and graphically enhanced pictures of fetuses at various stages of development. ${ }^{325}$ Abortion-rights supporters often criticize the visual emphasis of the pro-life movement

321 See generally MiRcea EliAde, PATTERNS in COMPARATIVE RELIGION (1976).

322 Kathryn Pyne Addelson, The Emergence of the Fetus, in FETAL SuBJECTS, FEminist Positions 26, 29 (Lynn M. Morgan \& Meredith W. Michaels eds., 1999).

323 See, e.g., Barbara Duden, Quick with Child: An Experience that Has Lost Its Status, 14 TECH. SoC'Y 335, 341, 343 (1992).

324 Camille S. Williams, Feminism and Imaging the Unborn, in THE SILENT SUBJECT: REFLECTIONS ON THE UNBORN IN AMERICAN CULTURE 61, 69 (Brad Stetson ed., 1996).

325 See, e.g., Rosalind Pollack Petchesky, Foetal Images: The Power of Visual Culture in the Politics of Reproduction, in REPRODUCTIVE TECHNOLOGIES: GENDER, MoTHERHOOD AND MEDICINE 57, 57-58 (Michelle Stanworth ed., 1987) (explaining that in the 1980s, prolife strategists set out "to make foetal personhood a self-fulfilling prophecy by making the foetus a public presence [in] a visually oriented culture"). The strategy has largely succeeded: "the curled-up profile, with its enlarged head and finlike arms . . . has become so familiar that not even most feminists question its authenticity (as opposed to its relevance)." ROSALIND POLIACK PETCHESKY, ABORTION AND WOMAN'S ChOICE: THE STATE, SEXUALITY, AND REPRODUCTIVE FREEDOM xiv (rev. ed. 1990). 
for showing inaccurate (or accurate but misleading) images, ${ }^{326}$ and prolifers respond by defending the meaningfulness and relevance of the displays. ${ }^{327}$

Thus, both sides appear to agree that our visual interpretation of fetal life is relevant to making judgments about fetal personhood. They disagree about which ways of visually presenting and understanding the fetus are the most accurate and revealing. My goal is not to say who is correct, but simply to say that the disagreement is about shared experience, not religion. It is about whether the pro-life visual understanding of the fetus is true to physical reality or mere propaganda.

Furthermore, the increasing availability of detailed ultrasound technology enables pregnant women to visually encounter the unborn child within her in a way that reveals its developing human form. For many women (by no means all), this encounter changes their assessment of the life growing within them and results in a change of heart about abortion. ${ }^{328}$ Many abortion-rights supporters cast doubt on the inferences about fetal personhood that many women and families draw from seeing an ultrasound of their unborn child. ${ }^{329}$ Here, too, I do not seek to resolve the dispute, but simply to point out that the disagreement concerns the proper interpretation of ordinary visual experience, not religion.

Moving from visual sensation to relational experience, ${ }^{330}$ the bonds that pregnant women form-or do not form-with their unborn children

326 See, e.g., Carol Sanger, Seeing and Believing: Mandatory Ultrasound and the Path to a Protected Choice, 56 UCLA L. REv. 351, 367-73 (2008) (arguing that ultrasound and visual imagery about the fetus is not exclusively a visual experience; our visual perception is shaped by political and social context, including the role of the sonographer as interpreter of the visual display).

327 For instance, the Alabama legislature justified its legislation requiring that women seeking abortions first receive the opportunity to see an ultrasound on the grounds that ultrasound provides valuable information (part of the "informed consent" for the procedure) that abortion doctors are unlikely to provide: "In most instances, the woman's only actual contact with the physician occurs simultaneously with the abortion procedure, with little opportunity to receive counseling concerning her decision." Woman's Right to Know Act, ALA. CODE § 26-23A-2 (LexisNexis Supp. 2007).

328 See, e.g., John C. Fletcher \& Mark I. Evans, Maternal Bonding in Early Fetal Ultrasound Examinations, 308 NEW ENG. J. MED. 392, 392 (1983) (describing the responses of several women who were considering abortion to their ultrasounds. One woman said, "I feel that it is human. It belongs to me. I couldn't have an abortion now.").

329 See, e.g., Sanger, supra note 326, at 367-70, 372-73.

330 Relational experience is especially relevant for the abortion debate, because one of the primary contributions that feminism has made to ethics is to emphasize the centrality of relationships and connectedness with others as a source of moral knowledge. See, e.g., Elisabeth PORTER, Feminist Perspectives on ETHics 7 (1999) (explaining that in many strands of feminist theory, the experience of relationships is "fundamental to ethics"). The major objection to using relational experience as a basis for moral knowledge is that relationships tend to bias and prejudice moral reasoning, rather than enhance it. 
can be a powerful influence on their views of fetal personhood. Women come away from pregnancy (and abortion) with dramatically different experiences of and relationships to their developing child. The texture of this experience can dramatically influence women's understanding of the value of fetal life. Furthermore, these experiences shape the broader society's conception and valuation of the fetus, because "[w]e see the unborn through their mothers, if we see them at all." 331

For instance, in the case of an unwanted pregnancy, some women (not all) view the fetus as an "intruder" and a threat to their physical integrity and future. ${ }^{332}$ These ways of experiencing pregnancy and relating to the fetus tend to dehumanize it; or, insofar as the fetus is seen as having a human identity at all, its humanity is viewed as hostile and foreign. By contrast, many other pregnant women experience a deep personal bond with an unborn child whom they have already named and already view as a full member of their family. As one woman expressed it, "I became his mother long before that moment when I heard his first cry," and "from the moment I knew I was pregnant, I was different-a mother. I was aware of sheltering a developing life within my body." 333 This experience profoundly humanizes and personalizes the fetus.

Nor are these experiences limited to the pregnant woman carrying the unborn child. The father of the child, new grandparents, friends, and others may have similar experiences. Pregnancy and new life have dramatic consequences-both joyful and daunting-for individuals, families, and communities.

Ultrasound videos, fetal pictures, and a woman's sense of relationship with her unborn child do not prove (or disprove) fetal personhood in a philosophical sense. Nonetheless, for many people, both pro-life and pro-choice, these dimensions of sensory and relational

Feminists have persuasively replied that skepticism of relational ethics reflects a problematic, gender-biased account of moral reasoning, and that moral reasoning based on relationships is not a "bias," but simply reflects a "different social and moral understanding." Carol Gilligan, In a Different Voice: Women's Conceptions of Self and of Morality, 47 HARV. EdUC. REV. 481, 482 (1977).

331 Williams, supra note 324 , at 61 .

332 Eileen L. MCDonagh, Breaking the abortion Deadlock: From Choice to CONSENT 188 (1996). Similarly, fetal life has also been likened to a rapist, Donald $\mathrm{H}$. Regan, Rewriting Roe v. Wade, 77 MICH. L. REV. 1569, 1616 (1979); a dying violinist artificially attached to the woman's body, Judith Jarvis Thomson, A Defense of Abortion, 1 PHIL. \& PUB. AFF. 47, 48-49 (1971); and other images that suggest the alien and hostile nature of the fetus. For a collection of non-academic articulations of the experience of pregnancy and abortion by pro-choice women, see Brief for the Amici Curiae Women Who Have Had Abortions and Friends of Amici Curiae in Support of Appellees at 1-2, Webster v. Reprod. Health Servs., 492 U.S. 490 (1989) (No. 88-605).

333 Maria McFadden, Motherhood in the 90's: To Have or Have Not, in THE SILENT SUBJECT: REFLECTIONS ON THE UNBORN IN AMERICAN CULTURE 115, 115 (Brad Stetson ed., 1996). 
experience play an important part in forming our judgments about fetal personhood. Because the faith-versus-reason commentators acknowledge these types of experiences as secular and legitimate grounds for political judgment, it follows that pro-life conclusions about fetal personhood (and the contrary pro-choice ones, which are also rooted in experience) have a secular foundation. Thus, "history," "logic," and "shared experiences"the three paradigmatic types of secular reasoning-can all support a cogent secular case for viewing fetuses as human persons and protecting them against abortion through political means.

\section{CONCLUSION}

This Article brings to the surface, describes, and refutes a crucial and virtually unnoticed dynamic in the Supreme Court's abortion cases: a phenomenon that I have referred to as the underground Establishment Clause, or UEC. The UEC is a complex collection of arguments and rhetoric that originated in Roe and evolved over time in response to new criticisms and challenges. Despite its variations and development, the central feature of the UEC articulated in Roe has remained intact: the government cannot prohibit abortion based on the idea that fetuses are human beings, because that proposition is divisive, closely associated with religion, and therefore inappropriate for political bodies to decide. The UEC, as understood in this way, plays a central role in justifying the holding of Roe and later cases, because it ruled out the government's only hope for articulating a compelling interest for infringing the right to abortion: the interest in protecting fetal human persons against abortion in the same way that it protects born human persons against homicide.

However, I have shown that none of the Establishment Clause arguments against abortion restrictions are convincing, and that the government has rational and secular grounds for viewing fetuses as human persons and protecting them accordingly. Thus, the Court should bring the Establishment Clause dynamic of its abortion cases out from the underground, and openly consider whether protecting fetal persons against abortion is a "religious" goal that violates the First Amendment. If it were to draw the proper conclusion - that protecting fetal persons is a valid "secular" goal for government to pursue-then the foundations would be laid for the Court to re-evaluate the essential question that Roe refused to address: whether a fetus is a human being, such that the government has a compelling justification for protecting it against abortion. 